Atmos. Chem. Phys., 13, 10027-10048, 2013

www.atmos-chem-phys.net/13/10027/2013/

doi:10.5194/acp-13-10027-2013

(c) Author(s) 2013. CC Attribution 3.0 License.

\title{
Modeling the present and future impact of aviation on climate: an AOGCM approach with online coupled chemistry
}

\author{
P. Huszar ${ }^{1,4}$, H. Teyssèdre ${ }^{1, \dagger}$, M. Michou ${ }^{1}$, A. Voldoire ${ }^{1}$, D. J. L. Olivié ${ }^{1,3}$, D. Saint-Martin ${ }^{1}$, D. Cariolle ${ }^{1,2}$, S. Senesi ${ }^{1}$, \\ D. Salas Y Melia ${ }^{1}$, A. Alias ${ }^{1}$, F. Karcher ${ }^{1}$, P. Ricaud ${ }^{1}$, and T. Halenka ${ }^{4}$ \\ ${ }^{1}$ GAME/CNRM, Météo-France, UMR 3589, CNRS, Toulouse, France \\ ${ }^{2}$ Centre Europeén de Recherche et de Formation Avancée en Calcul Scientifique, CERFACS/CNRS, Toulouse, France \\ ${ }^{3}$ University of Oslo and CICERO, Oslo, Norway \\ ${ }^{4}$ Department of Meteorology and Environment Protection, Faculty of Mathematics and Physics, Charles University, Prague, \\ V Holešovičkách 2, Prague 8, 180 00, Czech Republic \\ $\dagger$ Deceased, April 2013
}

Correspondence to: P. Huszar (peter.huszar@mff.cuni.cz)

Received: 11 January 2013 - Published in Atmos. Chem. Phys. Discuss.: 11 February 2013

Revised: 6 September 2013 - Accepted: 9 September 2013 - Published: 11 October 2013

\begin{abstract}
Our work is among the first that use an atmosphere-ocean general circulation model (AOGCM) with online chemistry to evaluate the impact of future aviation emissions on temperature. Other particularities of our study include non-scaling to the aviation emissions, and the analysis of models' transient response using ensemble simulations. The model we use is the Météo-France CNRM-CM5.1 earth system model extended with the REPROBUS chemistry scheme. The time horizon of our interest is 19402100, assuming the A1B SRES scenario. We investigate the present and future impact of aviation emissions of $\mathrm{CO}_{2}, \mathrm{NO}_{\mathrm{x}}$ and $\mathrm{H}_{2} \mathrm{O}$ on climate, taking into account changes in greenhouse gases, contrails and contrail-induced cirrus (CIC). As in many transport-related impact studies, we distinguish between the climate impacts of $\mathrm{CO}_{2}$ emissions and those of non- $\mathrm{CO}_{2}$ emissions. Aviation-produced aerosol is not considered in the study. Our modeling system simulated a notable sea-ice bias in the Arctic, and therefore results concerning the surface should be viewed with caution. The global averaged near-surface $\mathrm{CO}_{2}$ impact reaches around $0.1 \mathrm{~K}$ by the end of the 21 st century, while the non- $\mathrm{CO}_{2}$ impact reaches $0.2 \mathrm{~K}$ in the second half of the century. The $\mathrm{NO}_{\mathrm{x}}$ emissions impact is almost negligible in our simulations, as our aviation-induced ozone production is small. As a consequence, the non- $\mathrm{CO}_{2}$ signal is very similar to the $\mathrm{CIC}$ signal. The seasonal analysis shows that the strongest warming due to aviation is modeled for the late summer and early autumn.
\end{abstract}

In the stratosphere, a significant cooling is attributed to aviation $\mathrm{CO}_{2}$ emissions $(-0.25 \mathrm{~K}$ by 2100$)$. $\mathrm{A}-0.3 \mathrm{~K}$ temperature decrease is modeled when considering all the aviation emissions, but no significant signal appears from the CIC or $\mathrm{NO}_{\mathrm{x}}$ forcings in the stratosphere.

\section{Introduction}

The environmental impact of global aviation has been a concern since the 1960s and early 1970s (Osmundsen, 1963; Johnston, 1971; Johnston and Quitevis, 1971). Since these pioneering studies, notable progress has been achieved in the understanding of aviation's impact on the environment, resulting in two major assessments. The first was undertaken by the Intergovernmental Panel for Climate Change (IPCC, 1999). More recently, Lee et al. (2010) provided a comprehensive report on the issue. They accounted for the impact of the emissions produced by aircraft on the atmospheric chemistry and climate alone. However, aircraft produce significant noise, especially around airports; therefore the health effects of aircraft noise are subject to research as well (e.g., Roselund et al., 2001).

Emissions of gases and aerosols from global aviation altering the chemical composition of the atmosphere and, consequently, the change of abundances in radiatively active gases and aerosols, have an impact on the radiative forcing (RF) 
and lead to temperature changes (e.g., Skeie et al., 2009). The condensation trail (contrail) formation from water vapor emissions and the induced cirrus cloud generate further RF from aviation.

The RF components from subsonic aviation originate from several processes (Lee et al., 2009). $\mathrm{CO}_{2}$ (carbon dioxide) emissions increase the $\mathrm{CO}_{2}$ levels and result in a positive $\mathrm{RF}$. The range of $25.0-28.0 \mathrm{~mW} \mathrm{~m}^{-2}$ was provided by the studies of Sausen et al. (2005) and Lee et al. (2009) for the years 2000 and 2005. Emissions of $\mathrm{NO}_{\mathrm{x}}$ (nitrogen oxides) trigger, through a chain of chemical reactions, the formation of $\mathrm{O}_{3}$ (ozone) (Grewe et al., 2002a, b), which produces a positive RF (Stevenson et al., 2004; Köhler et al., 2008; Myhre et al., 2011). Secondly, it causes a long-lived $\mathrm{CH}_{4}$ (methane) reduction that represents a negative RF (Stevenson et al., 2004). Finally, a long-term small $\mathrm{O}_{3}$ decrease is attributed to this methane reduction, resulting in a negative RF (Köhler et al., 2008). The RF estimates of the latter study for these three components are $30 \mathrm{~mW} \mathrm{~m}^{-2},-19 \mathrm{~mW} \mathrm{~m}^{-2}$ and $-11 \mathrm{~mW} \mathrm{~m}^{-2}$, respectively for the 2002 emissions. This gives a zero net forcing. Stevenson et al. (2004) reached the same conclusion, indicating an overall low RF due to aviation $\mathrm{NO}_{\mathrm{x}}$ emissions.

Aircraft emit water vapor $\left(\mathrm{H}_{2} \mathrm{O}\right)$, which is a greenhouse gas with a positive $\mathrm{RF}$ estimated at $2.8 \mathrm{~mW} \mathrm{~m}^{-2}$ by Lee et al. (2009) for 2005. However, the most recent study, Wilcox et al. (2012) updates $\mathrm{H}_{2} \mathrm{O}$ vapor $\mathrm{RF}$ to a smaller value of $0.9 \mathrm{~mW} \mathrm{~m}^{-2}$.

An important, routinely observed effect of aircraft $\mathrm{H}_{2} \mathrm{O}$ emissions is the formation of persistent contrails and contrail cirrus (Atlas et al., 2006). Contrails are line-shaped cirrus that form after mixing of the hot and moist air from the aircraft engines with the ambient air; for this to occur, the Schmidt-Appelman criterion (Schumann, 1996) must be fulfilled, which requires the air to be under a critical temperature and above a threshold humidity. Depending on the local meteorological conditions, a contrail can undergo shear, uplift and mixing, resulting in its areal extent - a contrail cirrus is formed. The contrail ice nuclei can also modify the natural cirrus cloudiness (Boucher, 1999). Hereafter, we will use the term "contrail-induced cloudiness" (CIC) to refer to contrails, contrail cirrus and natural cirrus modifications mentioned later. We also point out that the term "aviation-induced cloudiness" (AIC) is defined as well (Lee et al., 2010), which adds cloudiness generated by aircraft soot to CIC.

The detection (measurement), properties, formation, evolution and radiative effects of linear-shaped contrails and/or the contrail-induced cloudiness have been subject to a large number of studies (Zerefos et al., 2003; Schumann, 2005; Stordal et al., 2005; Gao et al., 2006; Hong et al., 2008; Frömming et al., 2011). The physical mechanism behind its formation is now well understood; however, due to the uncertainties in the modeling of its occurrence and of its properties varying in time and space, the calculation of the related RF is still marked by a low to very-low level of scientific under- standing (Lee et al., 2010). Current RF estimates lie in the $10-80 \mathrm{~mW} \mathrm{~m}^{-2}$ interval for the year 2005 (Lee et al., 2009). The most up-to-date CIC RF estimate is given by Burkhardt and Kärcher (2011), $31 \mathrm{~mW} \mathrm{~m}^{-2}$ for the year 2005.

Aircraft black carbon (BC) emissions represent a tiny fraction of the total emitted anthropogenic BC mass, but BC particles originating from aircraft engines are much smaller than from other sources. Thus the number concentration of $\mathrm{BC}$ is significantly perturbed by aviation (Hendricks et al., 2004). The RF estimates for BC recently given by Balkanski et al. (2010), are 0.1 or $0.3 \mathrm{~mW} \mathrm{~m}^{-2}$, depending on whether the considered BC is externally or internally mixed with sulphate. In contrast, a one order of magnitude larger negative $\mathrm{RF}$ is calculated by the same authors for aviation sulphate aerosols $\left(\sim 1 \mathrm{~mW} \mathrm{~m}^{-2}\right)$.

The total RF of aviation was evaluated by Sausen et al. (2005) for 2000, and recently by Lee et al. (2010) for 2005 , giving a positive $\mathrm{RF}$ of $47.8 \mathrm{~mW} \mathrm{~m}^{-2}$ and $55.0 \mathrm{~mW} \mathrm{~m}^{-2}$, respectively. These values included linear contrails (around $10 \mathrm{~mW} \mathrm{~m}^{-2}$ ), but excluded the aviationinduced cirrus cloudiness, which is very uncertain in terms of its related RF. The latter can, however, be estimated from the latest CIC estimate from Burkhardt and Kärcher (2011) at $21 \mathrm{~mW} \mathrm{~m}^{-2}$. The total $\mathrm{RF}$ from the aviation sector for the year 2005 is thus around $70-75 \mathrm{~mW} \mathrm{~m}^{-2}$.

The above positive RF represents a significant contribution to the total anthropogenic RF of $1660 \mathrm{~mW} \mathrm{~m}^{-2}$ (Lee et al., 2010), and it may be responsible for significant warming and other changes (e.g., precipitation). Furthermore, this forcing is expected to increase gradually towards the end of the $21 \mathrm{st}$ century (Skeie et al., 2009); therefore, its impact might rise as well. The climate system's response to a given radiative forcing is delayed due to its thermal inertia (Hansen et al., 2005). If only the land-surface and the ocean mixed layers are considered, the timescale of the response is 1 to $5 \mathrm{yr}$ (Olivié and Stuber, 2010). Taking into account the deep ocean response, this timescale changes to several centuries. In terms of intensity, the fast response contributes $60-80 \%$ of the total response. This inertial behavior has to be taken into account when modeling the transient phase of climate change (Olivié et al., 2012). A few studies have taken this into consideration when investigating the climate impact of aviation emissions (Ponater et al., 2005, 2006; Lim et al., 2007; Skeie et al., 2009), but they used simplified model approaches to calculate the impact of aviation on climate.

To investigate the long-term response of a varying anthropogenic forcing (such as aviation), including its geographic and vertical distributions, a more sophisticated approach using an AOGCM (atmosphere-ocean general circulation model) is required, as it describes the atmosphere, ocean, sea ice and the interactions between them in detail. This is certainly a computationally demanding task, and for the aviation impact, Olivié et al. (2012) is one of the few studies to adopt this approach. They assessed the climate impact of all transport sectors (road, shipping and aviation) for the 
period 1860-2100. The AOGCM they applied did not contain the detailed chemistry of the atmosphere, but a simplified $\mathrm{O}_{3}$ scheme (Cariolle and Teyssèdre, 2007). Therefore, the forcing agents (such as $\mathrm{CO}_{2}$, aerosols, etc.) perturbed by the specific transport sector were provided externally as global constants or 3-D fields. For ozone, two approaches were adopted: in the first one, they prescribed 3-D perturbed ozone fields, while a simplified ozone scheme was used in the second one. The CIC was not calculated online during the simulations, but an external data source served to track its presence in the model atmosphere and was later provided to the radiative code of the AOGCM.

Here we present a novel approach for evaluating the climate-chemistry impact of aviation emissions: we use a similar AOGCM to that of Olivié et al. (2012), the novelty being that, in our AOGCM, we consider online coupled chemistry from the mid-troposphere through the stratosphere, regions that encompass the altitudes where the majority of air traffic and therefore its emissions occur. A number of radiatively active chemical species are then considered by the radiative scheme (see Michou et al. (2011) for details).

This allows us to use the aviation emissions as inputs to the model (i.e., not the concentration perturbations) and to account for all the chemical processes triggered by these emissions.

The main focus of this paper is the transient 3D temperature response to the aviation emissions over the 1940-2100 period (in contrast to the equilibrium studies of Ponater et al. (2005) or Rap et al. (2010)), investigating the 1940-2100 period. We therefore expect a smaller climate signal than the corresponding equilibrium response (Ponater et al., 2005). This offers the potential for obtain results of small or no significance; however, the transient response is what will actually occur, in contrast to the more theoretical equilibrium response.

In terms of forcing agents, we consider $\mathrm{CO}_{2}$ and $\mathrm{NO}_{\mathrm{x}}$ emissions; they represent the vast majority of the material emitted from aircraft engines. We account for water emissions only in the form of contrail ice particles and not as water vapor, assuming its radiative impact to be negligible, as confirmed recently by Wilcox et al. (2012). Previous studies (e.g., Balkanski et al., 2010; Olivié et al., 2012) have shown that aerosol originating from the aviation sector has a small direct radiative effect, so we did not consider aviation-related aerosols (soot and sulphates) in our study. It must be however noted, that, in contrast, the indirect radiative effect of these aerosols is qualified as possibly large and very uncertain in current studies (Liu et al., 2009; Hendricks et al., 2009). As in many transport-related impact studies, we will distinguish between the climate impacts of $\mathrm{CO}_{2}$ emissions and those of non- $\mathrm{CO}_{2}$ emissions. Further, we present the $\mathrm{NO}_{\mathrm{x}}$ impact, i.e., the impact of the $\mathrm{NO}_{\mathrm{x}}$ emissions alone, and the CIC impact, i.e., the impact of the contrails and the induced cirrus. Finally, the total aviation impact is evaluated.

\section{Tools and experimental set-up}

\subsection{The CNRM-CM model}

In our work, we used a chemistry-climate model that is an extension of the CNRM-CM5.1 ocean-atmosphere general circulation model, which is extensively described in Voldoire et al. (2013). This extension takes an online chemistry scheme into account(see the description of this scheme in Sect. 2.2).

In summary, CNRM-CM is a state-of-the-art general circulation model that was developed jointly by CNRM-GAME (Centre National de Recherches Météorologiques - Groupe d'études de l'Atmosphère Météorologique) and CERFACS (Centre Européen de Recherche et de Formation Avancée) in order to contribute to phase 5 of the Coupled Model Intercomparison Project (CMIP5, see http://cmip-pcmdi.llnl.gov/ cmip5/experiment_design.html). CNRM-CM5.1 includes atmospheric model ARPEGE-Climat (v5.2), ocean model NEMO (v3.2; Madec, 2008), land surface scheme ISBA and sea-ice model GELATO (v5; Salas Y Melia, 2002; Voldoire et al., 2013), coupled through the OASIS (v3; Valcke, 2006) system. The horizontal resolution of the atmosphere is about $1.4^{\circ}$ and $1^{\circ}$ for the ocean. The atmospheric component uses the Morcrette et al. (2001) scheme over 6 bands for the solar radiation, and the RRTM scheme (Mlawer et al., 1997) for the long-wave radiation. Seven gases are considered as absorbers: $\mathrm{H}_{2} \mathrm{O}, \mathrm{CO}_{2}, \mathrm{O}_{3}, \mathrm{CH}_{4}, \mathrm{~N}_{2} \mathrm{O}, \mathrm{CFC} 11$ and $\mathrm{CFC} 12 . \mathrm{O}_{3}$ is a prognostic variable with photochemical production and loss rates computed offline by a 2-D zonal chemistry model (MOBIDIC; Cariolle and Teyssèdre, 2007). $\mathrm{H}_{2} \mathrm{O}$ is a prognostic variable and the other 5 absorbents are prescribed to a uniform value that evolves on a yearly basis. The climatology of tropospheric aerosols by Szopa et al. (2013) is prescribed, while the land surface scheme has been externalized from the atmospheric model through the SURFEX platform. It includes new developments, such as a parameterization of sub-grid hydrology, a new soil-freezing scheme and the ECUME bulk parameterization for ocean surface fluxes.

The CNRM-CM default version has 31 vertical levels, with 5 levels in the stratosphere (set-up used in Olivié et al. (2012), for instance). For stratospheric chemistry studies, the number of vertical levels has been increased to 60 (up to $0.07 \mathrm{hPa}$ ), 24 of which are in the stratosphere. This represents an improvement with regard to previous studies, especially those that focused on the chemical perturbation caused by aviation emissions (e.g., Hoor et al., 2009; Koffi et al., 2010; Hodnebrog et al., 2012).

In parallel, the time step of the simulations was changed from 30 to $15 \mathrm{~min}$. Additionally, as there are 55 3-D supplementary species, the horizontal resolution was reduced from $1.4^{\circ}$ to $2.8^{\circ}$ to reduce computational costs. As a consequence of this resolution decrease, the horizontal diffusion and gravity wave drag have been adjusted. Finally, to address the aviation impact, the aircraft $\left(\mathrm{CO}_{2}, \mathrm{NO}_{x}\right)$ and lightning emissions $\left(\mathrm{NO}_{x}\right)$, and a plume representation have been added to the 
model. These points are detailed in the following paragraphs. This version of CNRM-CM costs about $21 \mathrm{~h}$ of elapsed time to simulate one year on the NEC supercomputers of MétéoFrance.

\subsection{The chemistry used in our simulations}

The chemistry module embedded in CNRM-CM is based on the REPROBUS stratospheric chemistry scheme (Lefèvre et al., 1994). It does not include the detailed non-methane hydrocarbon (NMHC) chemistry specific to the lower troposphere. Lee et al. (2010) report on the impact of aircraftinduced ozone changes when considering the NMHC chemistry in global models, quantifying the difference in $\mathrm{O}_{3}$ production in the lower and free troposphere. A few studies have examined this issue; most recently, Kentarchos and Roelofs (2002) indicate that their chemistry-climate model simulates an increase in $O_{3}$ of up to $12 \%$ when including the NMHC chemistry in their model. However, for the rest of the atmosphere, including the upper free troposphere from $560 \mathrm{hPa}$ up to the lower mesosphere (about $70 \mathrm{~km}$ ), the chemical reactions of our scheme correspond to those of state-of-theart chemistry-climate models (see Morgenstern et al. (2010); SPARC (2010)). This scheme calculates the evolution of 55 species with the JPL chemical kinetics of Sander et al. (2006) using 160 gas-phase reactions.

The chemistry is computed down to the $560 \mathrm{hPa}$ level, while for higher pressures the mixing ratios of a number of species (namely $\mathrm{N} 2 \mathrm{O}, \mathrm{CH} 4, \mathrm{CO}, \mathrm{CO} 2, \mathrm{CFC} 11$, $\mathrm{CFC} 12, \mathrm{CFC} 113, \mathrm{CCl} 4, \mathrm{CH} 3 \mathrm{CCl}$, $\mathrm{CH} 3 \mathrm{Cl}, \mathrm{HCFC} 22$, $\mathrm{CH} 3 \mathrm{Br}, \mathrm{H} 1211, \mathrm{H} 1301, \mathrm{Ox}, \mathrm{O} 3, \mathrm{Cly}, \mathrm{Bry}, \mathrm{NOy})$ are relaxed towards evolving global mean surface abundances (see SPARC (2010) for the ozone-depleting substances and greenhouse gases, and the CNRM-CCM technical documentation for the other compounds).

Explicit washout of chemical species is not considered in this version of the model, and neither are convective and turbulent transport. In addition, three types of particles are considered in the heterogeneous reactions: liquid stratospheric aerosols and polar stratospheric clouds (PSCs) that include water ice and NAT (nitric acid trihydrate) (see Teyssèdre et al. (2007); Michou et al. (2011); Morgenstern et al. (2010) for further details).

It is important to note that state-of-the art CCMs rarely consider tropospheric chemistry because of the computer resources required (among the 18 models of CCMVal-2, only 3 represented tropospheric chemical reactions; see Morgenstern et al. (2010)). The chemical scheme we use is fully suitable for the study of all the processes within the stratosphere, the UTLS and down to the middle troposphere; the latter two regions are of the highest importance for studying the aviation impact. This scheme has been evaluated in a large number of publications, as the CCMVal-2 effort was aimed at assessing CCM performance, both individually and collectively, among 17 other CCM models. The evaluated processes cover radiation, stratospheric dynamics, transport in the stratosphere, stratospheric chemistry, UTLS, natural variability of stratospheric ozone, long-term projections of stratospheric ozone, and the effects of the stratosphere on the troposphere. A number of CCMVal-2-related publications appear in Michou et al. (2011).

The 3-D distribution of the seven absorbing gases (listed in Sect. 2.1) is then provided by the chemistry module of CNRM-CCM and interacts with the radiative calculations.

\subsection{Emission data}

The emission data we used were developed within the QUANTIFY project, an integrated project funded through the EU-Framework Programme 6 (Lee et al., 2005) (see www.ip-quantify.eu). For aviation, they consist of 3-D data with a horizontal resolution of $1^{\circ} \times 1^{\circ}$ and $610 \mathrm{~m}$ vertical spacing of up to $14 \mathrm{~km}$.

These data contain monthly totals of fuel consumption and emissions for $\mathrm{NO}_{\mathrm{x}}$ and soot in $\mathrm{kg} g r i d b o x^{-1}$ month $^{-1}$. They are only available for the years 2000, 2025, 2050, and 2100 (see Fig. 1 for the 2000 and 2100 horizontal and zonally averaged fuel consumption distribution). For the period 1940-2100, time series of global emission estimates are also included (see Fig. 2). In 1940, the emissions are identically zero, since this year is considered to be the beginning of significant aviation activities (Sausen and Schumann, 2000). Until 2020, the FESG forecast values are adopted (FESG, 2008), which assumes that the fuel efficiency continues with recent trends and that $\mathrm{NO}_{\mathrm{x}}$ improvements commensurate with insertion of the best in present-day technology. The QUANTIFY data set does not explicitly contain military aviation emissions; however, the civil aviation emission patterns are scaled to the IEA aviation fuel-burn totals.

To provide 3-D emission data for years other than those available in the emission inventory (i.e., for the whole period 1940-2100), we linearly interpolated the emissions in time and normalized them with their annual totals.

When assessing the role of the $\mathrm{NO}_{\mathrm{x}}$ aviation emissions, the lightning $\mathrm{NO}_{\mathrm{x}}\left(\mathrm{LNO}_{\mathrm{x}}\right)$ has to be taken into account, since several studies (Bernsten et al., 1999; Grewe, 2003; Schumann and Huntrieser, 2007) have shown that it is another major source of $\mathrm{NO}_{\mathrm{x}}$ in the atmosphere. This has important implications for the atmospheric chemistry and climate, and disregarding $\mathrm{LNO}_{\mathrm{x}}$ while calculating the aviation $\mathrm{NO}_{\mathrm{x}}$ impacts (which is about 5 times smaller than $\mathrm{LNO}_{\mathrm{x}}$ for present days) could lead to erroneous conclusions (Grewe, 2003). Therefore, we consider $\mathrm{LNO}_{\mathrm{x}}$ in our study as well. The data are taken from the ANCAT lightning $\mathrm{NO}_{\mathrm{x}}$ emission monthly climatology defined for the year 1992. For other years, we applied a scaling to the global mean surface temperature, as suggested by Schumann and Huntrieser (2007), who estimate a $10 \%$ increase in lightning activity and emitted $\mathrm{LNO}_{\mathrm{x}}$ for each $1 \mathrm{~K}$ of global mean surface temperature increase. 

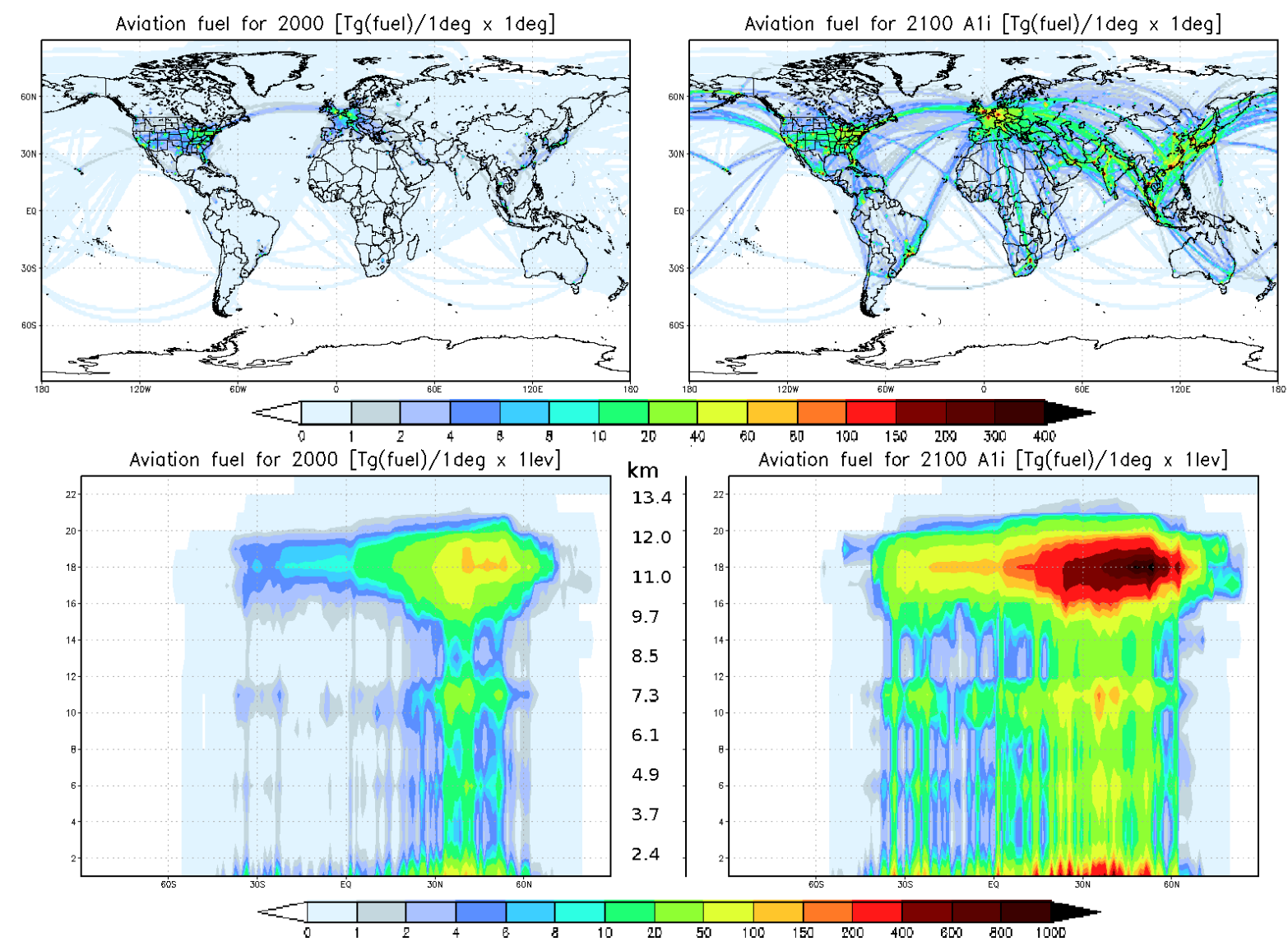

Fig. 1. Vertically (upper row) and zonally (bottom row) integrated aviation fuel consumption ( $\operatorname{Tg}\left(\right.$ fuel) $\left.\mathrm{yr}^{-1}\right)$ for the years 2000 (left) and 2100 (right), assuming the A1(i) scenario (Lee et al., 2005).

Emissions from aviation and lightning had to be implemented into CNRM-OACCM that did not consider either 2-D or 3-D emissions originally. They are read in by the model at the beginning of each simulated month, interpolated to the model grid and converted to emission densities that the model uses in the continuity equations to calculate the temporal evolution of the chemical species. We also adopted the temporal disaggregation of the monthly emission values given by Wilkerson et al. (2010). They provide weekly and hourly global profiles, so profiles are the same for every geographic region and reflect the evolution of the global emission value, and not the actual local variation of the emissions.

\subsection{Parameterizations}

The small-scale processes during the dilution of the aircraft emission plume cannot be explicitly resolved in our experimental set-up due to our coarse model resolution. However, these processes can imply changes in the model resolved scale; e.g., they can lead to modified chemical species concentrations and/or can consequently have radiative impacts.
One of these subgrid scale processes is the chemical evolution of the $\mathrm{NO}_{\mathrm{x}}$ emissions in the aircraft engine plume and the subsequent ozone formation. Several authors (e.g., Kraabøl et al., 2002; Cariolle et al., 2009, and references therein) have shown that disregarding the chemical nonlinearities in the $\mathrm{NO}_{\mathrm{x}}$ plumes behind the aircraft by applying instantaneous dilution at the model scale (as it is usually done in chemistry transport models - CTM) leads to increased $\mathrm{NO}_{\mathrm{x}}$ concentrations and ozone formation. Cariolle et al. (2009) developed a parameterization to account for this in large-scale CTM. The method, which has also been successfully applied to the ship $\mathrm{NO}_{\mathrm{x}}$ emissions (Huszar et al., 2010), introduces a "fuel" tracer with a certain lifetime that traces the amount of material in the plume. The large-scale $\mathrm{NO}_{\mathrm{x}}$ and $\mathrm{O}_{3}$ concentrations are then modified according to the concentration of this tracer using an effective reaction rate for the ozone formation. The method of Cariolle et al. (2009) has been implemented in CNRM-CCM.

Another aspect of the subgrid scale processes occurring in the aircraft plume is the condensation of the emitted water vapor, and the subsequent formation of contrails and 

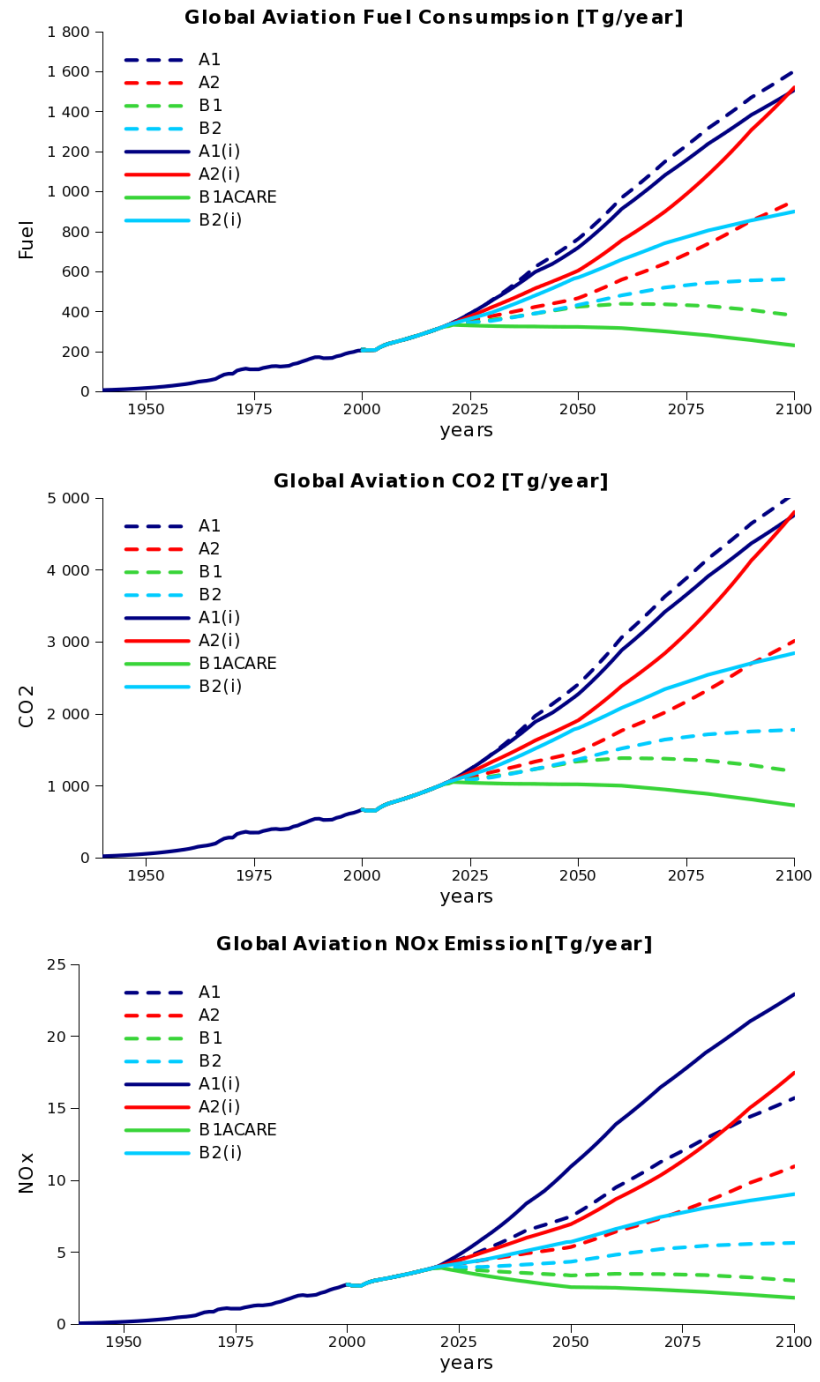

Fig. 2. Global annual fuel consumption: $\mathrm{CO}_{2}$ and $\mathrm{NO}_{\mathrm{x}}$ emissions $\left(\mathrm{Tg} \mathrm{yr}^{-1}\right)$ from aviation for the period 1940-2100 for different scenarios from the QUANTIFY project (Owen et al., 2010). In our simulations, the A1(i) scenario is considered.

contrail cirrus (depending on the meteorological conditions). We have not considered a detailed parameterization of the formation and evolution of the contrails. However, as the radiative effects of the CIC are of great importance and cannot be neglected, we have developed a simplified treatment of these processes and their related radiative effects. Our method, similar to that of Olivié et al. (2012), is summarized below.

We introduced a contrail tracer (similar to the "fuel" tracer mentioned above) with a certain lifetime $(15 \mathrm{~h})$. The distribution of the tracer is calculated online within the model in the same way as other gases. The modeled distribution of this tracer on the $250 \mathrm{hPa}$ level, representing the main flight level, is plotted in Fig. 3 (left). CIC is expected to form where the temperature is less than $-40{ }^{\circ} \mathrm{C}$ and the relative humidity exceeds $80 \%$. For every model integration step in model grid points fulfilling these conditions, we add the contrail tracer concentration, multiplied by a given factor, to the large-scale cloud ice mixing ratio. To obtain the value of this multiplicative factor, we conducted several annual simulations for the year 2005 in order to tune this factor to obtain an appropriate annual global value of the top-of-the-atmosphere radiative forcing for the contrail and contrail-induced cirrus for 2005 . The target value, taken from Burkhardt and Kärcher (2011), was $31 \mathrm{~mW} \mathrm{~m}^{-2}$, representing the most recent estimate. This factor obtained for 2005 is held constant between 1940 and 2100. The distribution of the TOA radiative forcing due to CIC for the year 2005 is seen in Fig. 3. It corresponds well to that of Burkhardt and Kärcher (2011): maximum values (over $300 \mathrm{~mW} \mathrm{~m}^{-2}$ ) are located over central Europe and the eastern U.S., and large parts of Europe and the U.S. encounter CIC RF over $100 \mathrm{~mW} \mathrm{~m}^{-2}$. Our CIC radiative forcing estimates over eastern Asia are higher than those of Burkhardt and Kärcher (2011), with maxima exceeding $300 \mathrm{~mW} \mathrm{~m}^{-2}$, while their values lie between 100 and $300 \mathrm{~mW} \mathrm{~m}^{-2}$. This can be explained by differences in contrail cirrus treatment (simple parameterization on the one hand vs. a more sophisticated contrail-cirrus module on the other), differences in the average thermodynamic conditions (temperature and humidity) simulated over east Asia, and, finally, differences in the emission inventory.

We did not consider the diurnal variations of the CIC occurence. Recently, Chen and Gettelman (2013) performed updated calculations of CIC radiative forcing using high temporal resolution aviation emissions, and showed that this diurnal cycle reduced the RF by $55 \%$ and $25 \%$ for linear contrails and contrail cirrus, respectively. Consequently, they obtained a global CIC forcing of $0.015 \mathrm{~mW} \mathrm{~m}^{-2}$. However, the maximum RF they computed over Europe and the U.S. is similar to ours.

As pointed out in the model description, the chemistry is resolved in the stratosphere and down to the midtroposphere. Chemical processes are not considered in the lower troposphere, where concentrations are relaxed towards climatological values that represent lower boundary conditions. When performing various simulations with perturbed aviation effects (e.g., simulations with/without aviation $\mathrm{CO}_{2}$ emissions; see further below), these lower boundary conditions have to reflect the situation that would occur if the whole troposphere were treated by explicit chemistry. In the case of $\mathrm{CO}_{2}$, an increase occurs due to aircraft emissions, while in the case of methane, aircraft $\mathrm{NO}_{\mathrm{x}}$ enhance $\mathrm{OH}$ concentrations, which accelerate methane reduction through a chemical reaction with $\mathrm{OH}$. Therefore, we have prescribed the aviation $\mathrm{CO}_{2}$ contribution and methane reduction in the tropospheric relaxation values.

For $\mathrm{CO}_{2}$, Skeie et al. (2009), who use the same emission inventory as this study, provide the aviation $\mathrm{CO}_{2}$ contribution 


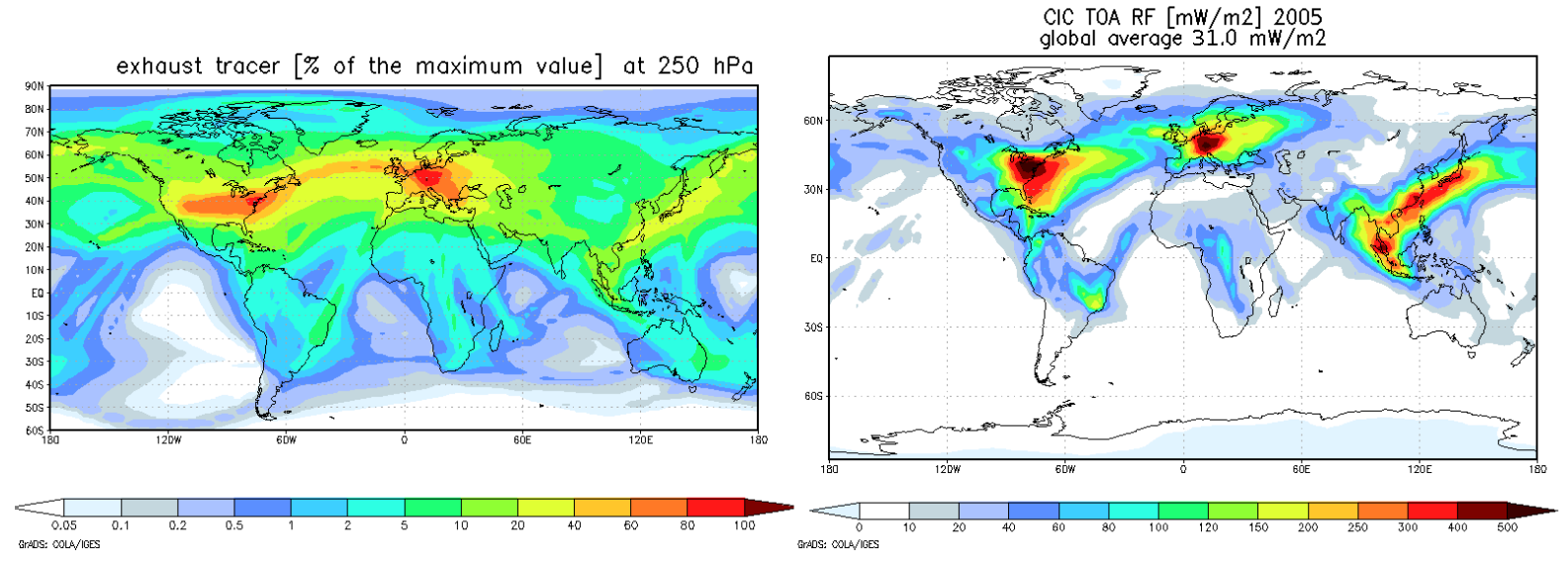

Fig. 3. On the left, annual mean horizontal distribution of the contrail tracer at $250 \mathrm{hPa}$ as percentage of the maximum value. On the right, annual average TOA radiative forcing of CIC in $\mathrm{mW} \mathrm{m}^{-2}$. Both figures are for the year 2005 .
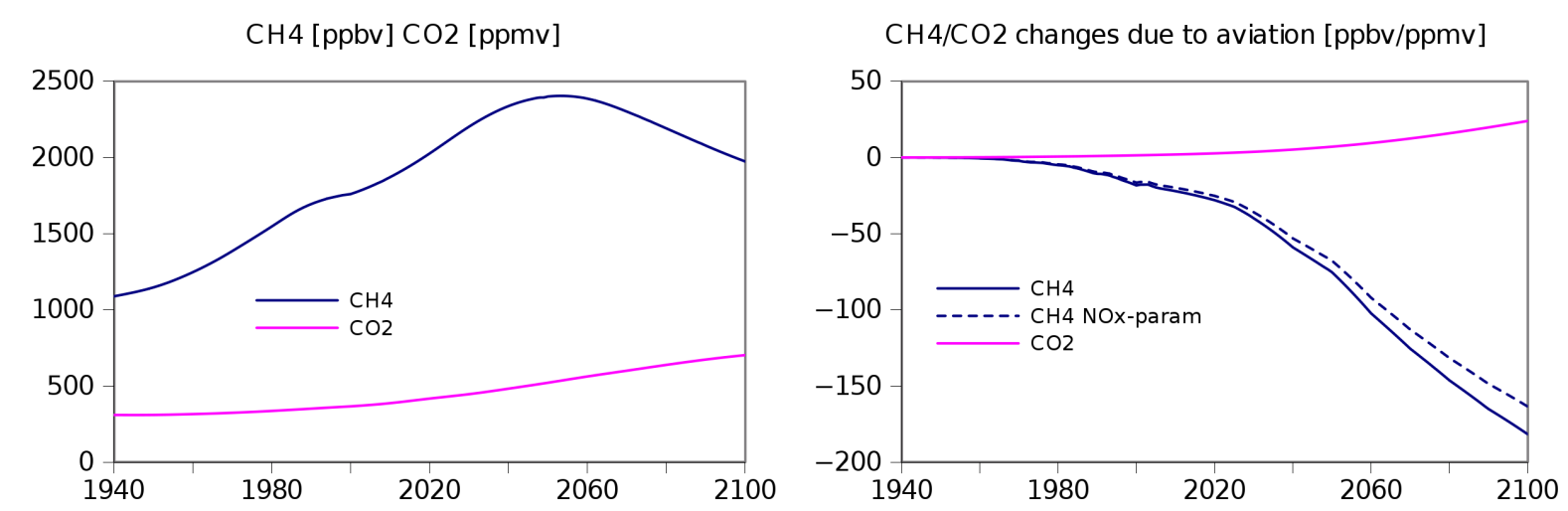

Fig. 4. On the left, evolution of methane and $\mathrm{CO}_{2}$ according to the $\mathrm{A} 1 \mathrm{~B}$ scenarios. On the right, calculated methane reduction due to aviation $\mathrm{NO}_{\mathrm{x}}$ emissions for the $\mathrm{A} 1 \mathrm{~B}$ scenario with (dashed line) and without (bold lines) $\mathrm{NO}_{\mathrm{x}}$ plume parameterization, and $\mathrm{CO}_{2}$ changes according to the A1(i) scenario.

until the end of the 21st century. The evolution of this contribution in ppmv is plotted in Fig. 4 (right, pink line).

The magnitude of the methane reduction due to aviation $\mathrm{NO}_{\mathrm{x}}$ emissions has been calculated following Olivié et al. (2012). They used the hydroxyl radical perturbation due to aviation for present as well as for 2025 and 2050 conditions in 3 different CTMs (Hodnebrog et al., 2011) to calculate the methane lifetime reduction and the consequent reduction in its concentration. For intermediate years from 1940 to 2100 we inter- and extrapolated the $\mathrm{OH}$ enhancement and therefore the methane changes.

It is important to note that these results did not consider the in-plume chemical non-linearities mentioned earlier, which result in a lower $\mathrm{OH}$ enhancement and, subsequently, in a smaller methane reduction. Kraabøl et al. (2002) calculated that the change in the methane lifetime becomes $\sim 9 \%$ smaller when plume processes are considered. We used this correction in our methane lifetime reduction. The 1940-2100 evolution of the $\mathrm{CO}_{2}$ and methane concentrations as well as of the perturbations due to the aviation $\mathrm{NO}_{\mathrm{x}}$ emissions with/without the $\mathrm{NO}_{\mathrm{x}}$ plume parameterization, for the $\mathrm{A} 1 \mathrm{~B}$ scenario, can be seen in Fig. 4 (right, blue line).

\subsection{Model simulations}

The goal of this study is to evaluate the aviation impact on chemistry and climate for the 1940-2100 period. This requires several simulations with perturbed aviation emissions to be performed to quantify their effects. To accomplish this, consistent initial conditions are essential for the year 1940, both for the atmospheric part of the model, including its chemical composition, and for the ocean and the sea ice. Another task that has to be performed before the "impact simulations", i.e., the experiments over the period 1940-2100 considering the aviation emissions, is to ensure that the chosen model configuration is able to simulate the 
Table 1. Sensitivity simulations performed in the study, and identification of aviation forcings. All sensitivity simulations have been performed over 1940-2100, with online chemistry.

\begin{tabular}{llccc}
\hline No. & Simulation ID & $\mathrm{CIC}$ & $\mathrm{CO}_{2}$ & $\mathrm{NO}_{\mathrm{x}}$ \\
\hline 1 & ALL & yes & yes & yes \\
2 & noCIC & no & yes & yes \\
3 & noCICnoCO2 & no & no & yes \\
4 & noCICnoNO $_{\mathrm{x}}$ & no & yes & no \\
5 & noAVIATION & no & no & no \\
\hline
\end{tabular}

climate system reasonably, without significant biases and trends when the forcings are set constant.

To meet these requirements, a 100-yr spinup was integrated under the 1860 conditions (i.e., greenhouse gas concentrations - GHG and solar constant). In this spinup, the online chemistry was turned off. After this spinup, the model was run further towards the end of the 21 st century with forcings according to the A1B scenario (referred to as DEFnochem). In 1920, a simulation in which the chemistry scheme is activated was started (referred to as DEFchem). 1920-1940 are then considered as spinup years to allow the chemical composition of the atmosphere to be in equilibrium with the mean climate of the model. We have verified that 20 years are enough to initialize the chemistry in order to have consistent initial conditions for 1940.

For the period 1940-2100, we performed several experiments with aviation forcings $\left(\mathrm{CO}_{2}, \mathrm{NO}_{\mathrm{x}}, \mathrm{CIC}\right)$ turned off/on (i.e., whether the related emissions or the contrails are considered or not). These sensitivity simulations are summarized in Table 1.

All the effects are accounted for in the experiment denoted "ALL". In the noCIC experiment, the effect of contrails and contrail-induced cirrus is removed. In the "noCICnoCO2" experiment, we also removed the $\mathrm{CO}_{2}$ emissions. The same was done for the $\mathrm{NO}_{\mathrm{x}}$ emissions ("noCICnoNO ${ }_{\mathrm{x}}$ "). Lastly, the "noAVIATION" experiment considers no aviation emissions at all.

In order to identify the climate signal caused by the aviation effects, we have to account for the effect of the variability of the modeled climate. We achieved this by performing ensembles of a few members for all "impact simulations" (1-5 in Table 1). There is no "a priori" knowledge of how many members are required in order to separate the signal information from the noise (A. Ribes, personal communication, 2013), so we decided, on the basis of our computer and time resources, to run ensembles with 3 members each, as in Olivié et al. (2012)). With the online coupled chemistry, the number of degrees of freedom is increased and this choice of 3 members is probably too small, but unfortunately it was not possible to run more members.
These ensembles were performed over the 2000-2100 period, as we expect the impact of aviation to be negligible for the 1940-1999 period, following Olivié et al. (2012). The year 2000 perturbation required for the 2nd and 3rd members of the mini-ensemble was obtained by restarting from 1 January 1999 and 2001 instead of 2000, as was done in the 1 st (original) member. Hereafter, results shown for the 2000 2100 period will by default represent ensemble means from these three simulations, unless explicitly stated otherwise.

In this study we have chosen not to apply emissions scaling as done in Ponater et al. (2005); Rap et al. (2010); Olivié et al. (2012)). Scaling relies on the hypothesis that the response is a linear function of emissions, allowing emissions to be multiplied by a factor and dividing the response by the same factor. Indeed, the hypothesis of a linear response to aviation emissions is questioned in some of the same studies. More specifically, Rap et al. (2010) found that for contrails, although RF behavior is sufficiently linear for a global mean $\tau$, it is considerably less linear for the larger optical depths. We thus opted for a more realistic approach, turning on/off the related unscaled emissions. Without scaling, the signal is weak and more difficult to detect, given the large variability of the climate system. To avoid this drawback while at the same time increasing the signal-to-noise ratio, it was decided to run simulations in ensemble mode.

We applied statistical significance tests to the results, expecting that part of them would not be significant due to the known effect of aviation upon climate.

The impact of an individual emission or all aviation emissions has been evaluated as the difference of appropriate experiments, in particular:

- $\mathrm{CO}_{2}$ impact: noCIC experiment - noCICnoCO2 experiment

- $\mathrm{NO}_{\mathrm{x}}$ impact: noCIC experiment - noCICnoNO experiment

- CIC impact: ALL experiment - noCIC experiment

- non- $\mathrm{CO}_{2}$ impact: ALL experiment - noCICnoNO experiment

- Total impact: ALL experiment - noAVIATION experiment

\section{Results}

\subsection{Overall climate change since preindustrial times}

The modeled evolution of the global annual average nearsurface temperature (at $2 \mathrm{~m}$ ) between 1860 and 2100 is plotted in Fig. 5. The orange line denotes the experiment without interactive chemistry, which was used to spin up the ocean-atmosphere climate system under preindustrial conditions and to simulate the 1860-1920 climate evolution. The 


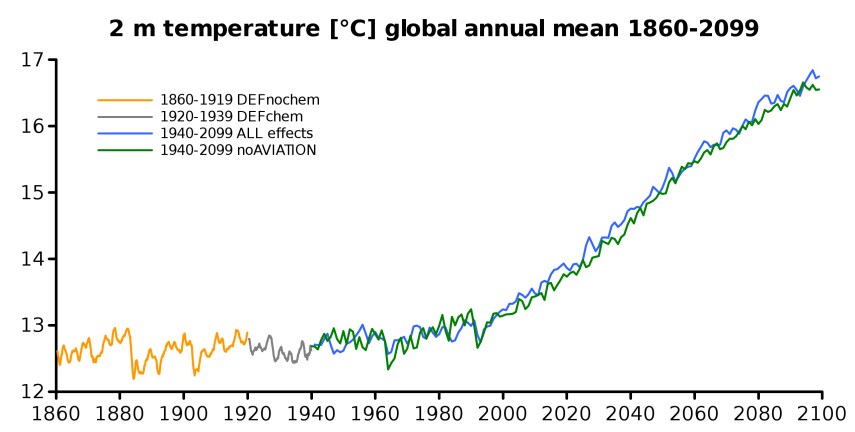

Fig. 5. Near-surface (at $2 \mathrm{~m}$ ) temperature evolution between 1860 and 2100 calculated by CNRM-CCM. The plot presents the "ALL" and the "noAVIATION" surface temperature for 1940-2100, the temperature from the chemical spinup run (DEFchem) for 19201940 and the run without online chemistry (DEFnochem) for 18602100.

grey line represents the 20-yr "chemical" spinup with the online chemistry turned on. The evolution of surface temperature between 1940 and 2100 is presented by the "ALL" and "noAVIATION" experiments. The modeled warming due to all anthropogenic forcing for both simulations with respect to 1860 is about $0.5,2.5$ and $4.0 \mathrm{~K}$ for the years 2000,2050 and 2100 , respectively. The corresponding IPCC (2007) values are approximately $0.7,2.2$ and $3.5 \mathrm{~K}$. The ALL experiment is slightly warmer throughout the 21 st century, indicating that the positive RF of the aviation emissions causes higher temperatures (detailed further in Sect. 3.3). The DEFnochem run without online coupled chemistry (i.e., which uses the CNRM-CM5.1 model) exhibits warming similar to the runs with online chemistry, indicating a comparable surface climate between the coupled and non-coupled runs.

The global average surface temperature for 1961-1990 is about $14^{\circ} \mathrm{C}$ (GISS, 2010), which is about $1^{\circ} \mathrm{C}$ higher than our results. In Olivié et al. (2012), where an earlier version of the model without interactive chemistry is used, the preindustrial mean surface temperature is about $1.0 \mathrm{~K}$ higher than in our version of the model. This difference in mean surface climate is quite constant over the 20th century and decreases over the 21 st century. Our version of the model obviously has a cold bias over the historical period and is more sensitive over the 21 st century. It must be noted that the cold bias remains when activating the chemistry component of the model, indicating that it is intrinsic to the atmosphere-ocean coupled system. The difference in mean historical climate is attributed to an overestimation of the Arctic sea ice in the model, especially over the Northern Atlantic. When running the same model, but with increased atmospheric resolution from $2.8^{\circ} \times 2.8^{\circ}$ to $1.4^{\circ} \times 1.4^{\circ}(\mathrm{CNRM}-\mathrm{CM} 5$, Voldoire et al (2013)), the Arctic sea-ice bias is much weaker. The sea-ice bias in our model is thus attributed to the coarse resolution of the atmospheric model. More precisely, the large difference

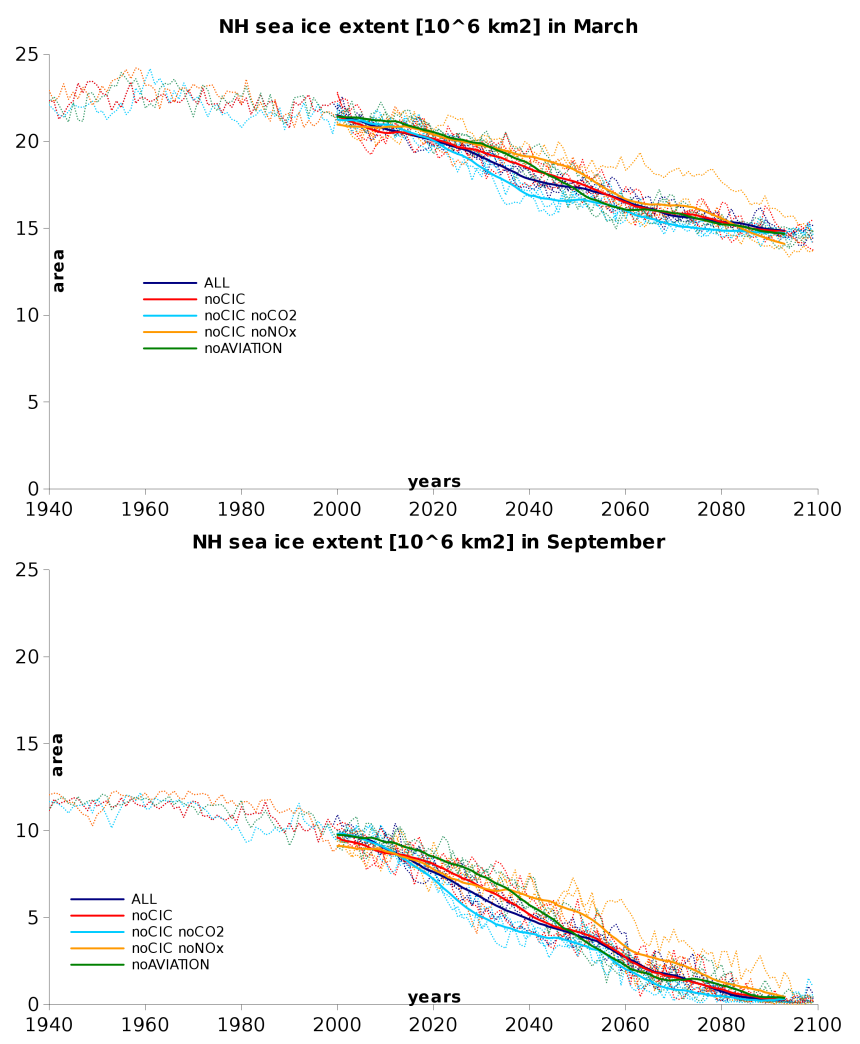

Fig. 6. The 1940-2100 evolution of the Arctic sea-ice area in September. Dotted lines represents yearly time series and solid lines the 11-yr running average of the three ensemble members for each experiment (see Table 1).

in resolution between the atmospheric model and the ocean model may generate inappropriate fluxes on the sea-ice edge.

In Fig. 6, we plotted the 1940-2100 evolution of the Arctic sea-ice area in September. The sea-ice extent over the 1950-1999 time span is about 12 million $\mathrm{km}^{2}$ in September, whereas it is estimated to be around 7 million $\mathrm{km}^{2}$ in observations by Fetterer et al. (2009). In Olivié et al. (2012), the simulated Arctic September sea-ice extent is closer to observations. By the end of the 21st century, the September sea-ice extent decreased to zero in both our simulations and in Olivié et al. (2012). Our simulations thus exhibit a much faster sea-ice melting during the 21 st century than Olivié et al. (2012), and great variability within the different simulations and members. The overestimation of the sea-ice cover over the 20th century explains the larger sensitivity of the climate system by increasing the potential sea-ice feedback under warmer conditions. The Arctic sea-ice loss under increased GHG concentrations is known to have a threshold behavior (Eisenman and Wettlaufer, 2009). It is well known that the speed of decrease is highly dependent on climate variability, and particularly on the ocean state. The uncertainty of this speed is higher with the overestimation of the 

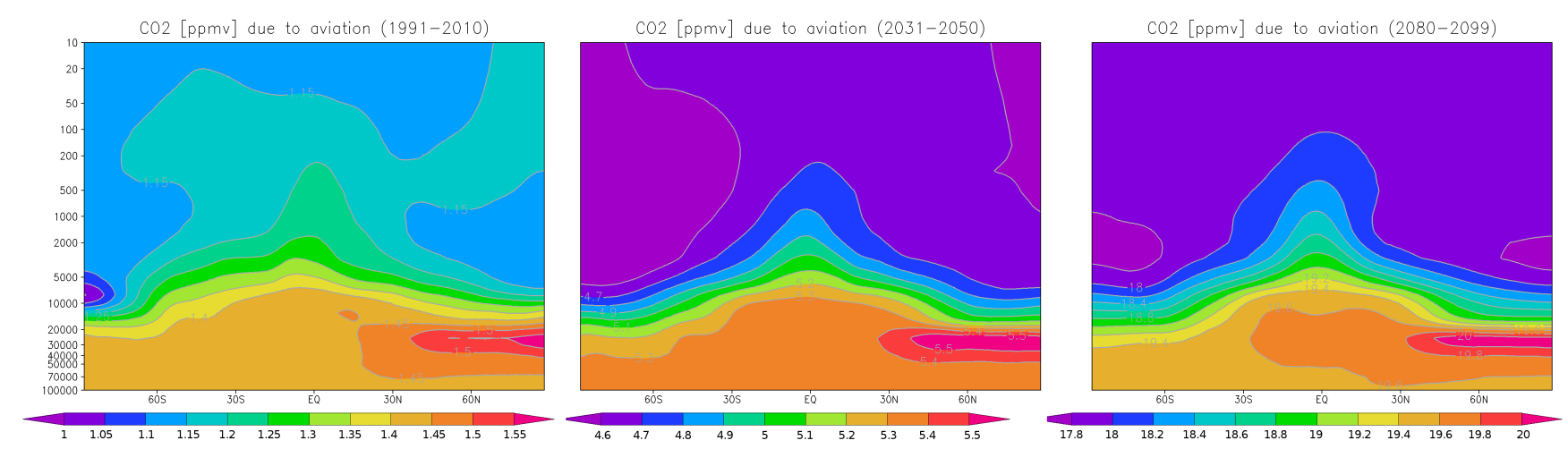

Fig. 7. Impact of aircraft $\mathrm{CO}_{2}$ emissions on the zonally averaged $\mathrm{CO}_{2}$ distribution for 1991-2010 (left), 2031-2050 (middle) and 2080-2099 (right) in ppmv. Note that the colorbar is different in each plot. The vertical axis corresponds to pressure in Pa.

sea-ice extent in our case. For this reason, the Arctic region may exhibit large differences in temperature between the different members, and these differences are not attributable to the difference in chemistry composition, but rather are due to the natural variability of the climate system. It has to be acknowledged here that this model bias has a negative impact on the possibility of detecting significant signals in our study. Moreover, the method of initialization of the different members is probably under-dispersive, given that an ocean state taken one year before or after is not very different in terms of ocean variability. Given these drawbacks, the differences in Arctic surface temperature in our simulations should be interpreted with caution.

\subsection{Impact on the atmospheric chemistry}

This section presents the changes in the amount and 3dimensional distribution of relevant air pollutants due to aviation emissions, with a focus on the $\mathrm{CO}_{2}$ and $\mathrm{NO}_{\mathrm{x}}$ emissions and the triggered ozone change.

We analyze the results over three 20-yr periods: 19912010, 2031-2050 and 2080-2099, representative of the present-day, near-future and far-future conditions.

Previous studies dealing with the aviation $\mathrm{CO}_{2}$ impact considered it to be uniformly distributed over the globe (e.g., Olivié et al., 2012), given its long lifetime. However, to some extent, the aviation contribution to the $\mathrm{CO}_{2}$ distribution is not uniform and its maximum is concentrated in the Northern Hemisphere. Figure 7 presents the zonally averaged aviation $\mathrm{CO}_{2}$ contribution in ppmv for 1991-2010, 2031-2050 and 2080-2099. The highest impact is located at the main flight levels over the Northern Hemisphere, where the maximum $\mathrm{CO}_{2}$ contribution is around $1.5,5.5$ and $20 \mathrm{ppmv}$, respectively, in the three periods. In the troposphere, the contribution goes down to $1.4,5.3$ and $19.5 \mathrm{ppmv}$, while in the stratosphere it decreases to $1.1,4.6$ and 17.8 ppmv, respectively.
The zonally averaged impact of aircraft $\mathrm{NO}_{\mathrm{x}}$ emissions on the $\mathrm{NO}_{\mathrm{x}}$ and ozone concentrations for June-July-August is presented in Fig. 8. For $\mathrm{NO}_{\mathrm{x}}$, significant changes occur at the main flight levels over the Northern Hemisphere, becoming important in the Southern Hemisphere as well in 2080-2099. The maximum changes occur between $40^{\circ} \mathrm{N}$ and $60^{\circ} \mathrm{N}$ and reach 10,50 and 100 pptv for the three periods, respectively. Impacts in the stratosphere are very small, and not statistically significant.

The aviation-induced, zonally averaged, ozone changes (Fig. 8, bottom row) are lower than 1 ppbv in the 19912010 period, and mostly not statistically significant. Significant changes occur only between the Equator and $30^{\circ} \mathrm{N}$. A more pronounced impact is modeled for 2031-2050 (up to $10 \mathrm{ppbv}$ ). In 2080-2099, this impact on ozone once more reaches 10 ppbv over the Northern Hemisphere and is higher across the whole troposphere than in 2031-2050. Ozone changes in the stratosphere ( 200 to $2 \mathrm{hPa}$ ) consist of decreases (up to $-20 \mathrm{ppb}$ ) in each of the three periods. These decreases are not, however, statistically significant. In contrast, in the mesosphere (above $1 \mathrm{hPa}$ ), statistically significant increases are modeled, reaching 5 ppbv and $10 \mathrm{ppbv}$ in 2031-2050 and 2080-2099, respectively.

\subsection{The mean global impact of different aviation emissions}

In this section we present the global mean temperature response due to different aviation emissions as the difference in the corresponding experiments (see previous section). Figure 9 shows these differences in the corresponding ensemble members (thin lines) and in the 11-yr running mean of the ensemble means (thick lines) for the temperature at the surface $(2 \mathrm{~m})$ and at selected pressure levels, i.e., $850,500,250$, 100 and $10 \mathrm{hPa}$, between 2000 and 2100 .

Aviation emissions induce a positive RF, causing a warming in the troposphere, at least when considering the equilibrium response (Rap et al., 2010). In the 20th century this effect is considered to be negligible, but with increasing 

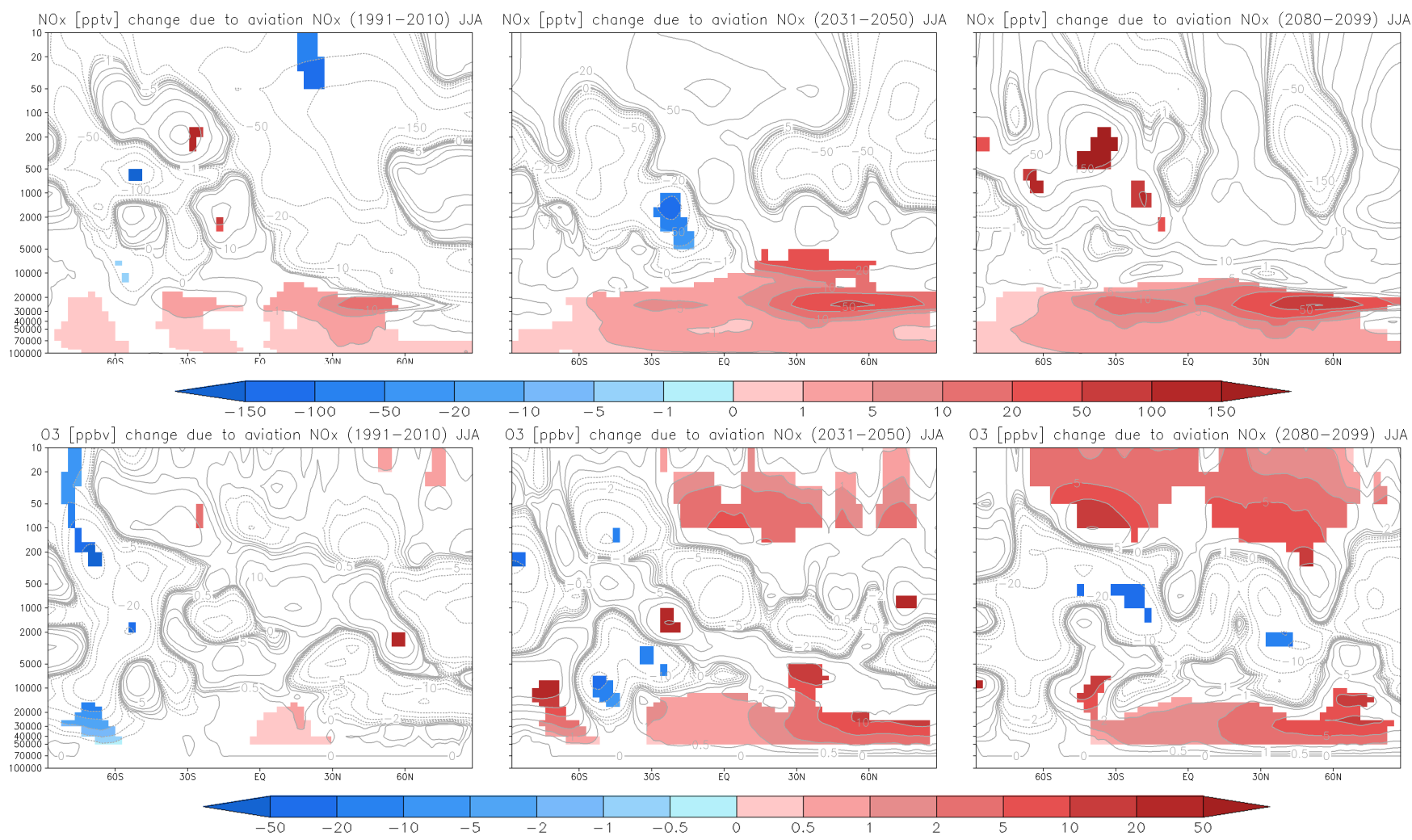

Fig. 8. The June-July-August impact of aircraft $\mathrm{NO}_{\mathrm{x}}$ emissions on the zonally averaged $\mathrm{NO}_{\mathrm{x}}$ (pptv, upper row) and $\mathrm{O}_{3}$ (ppbv, bottom row) distributions for 1991-2010 (left), 2031-2050 (middle) and 2080-2099 (right). The shaded areas show significant changes at the $95 \%$ level of confidence. The vertical axis corresponds to pressure in $\mathrm{Pa}$.

emissions it is expected to reach significant levels towards the end of the 21th century (Skeie et al., 2009; Olivié et al., 2012). In our simulations (see Fig. 9), the modeled impact on the 11-yr running mean temperature exhibits large variability throughout the century, and the signal is not obvious in all cases.

The increase in temperature due to aviation emissions is visible when considering the CIC effect (blue lines), the non$\mathrm{CO}_{2}$ effect (red lines) and the overall aviation effect (green lines), especially at higher levels of the troposphere, i.e., at 500 and $250 \mathrm{hPa}$. A warming of up to $0.1 \mathrm{~K}$ is predicted for the last two decades of the 21 st century due to the CIC impact or to the non- $\mathrm{CO}_{2}$ impact.

The expected warming of the troposphere due to aviation $\mathrm{CO}_{2}$ is visible only at the end of the 21 st century, reaching about $0.1 \mathrm{~K}$. During much of the 21 st century, the aviation $\mathrm{CO}_{2}$ causes cooling, in contrast to previous findings and scientific expectation.

Our modeling system does not simulate a significant change in global mean temperature in connection with aviation $\mathrm{NO}_{\mathrm{x}}$ emissions, and the non- $\mathrm{CO}_{2}$ impact, composed of the $\mathrm{CIC}$ and $\mathrm{NO}_{\mathrm{x}}$, is in line with the CIC impact.

Finally, for the troposphere, the overall aviation emission effect (green lines) results in a $0.2 \mathrm{~K}$ warming towards the end of the century at the highest levels (500 and $250 \mathrm{hPa}$ ). There, the warming is present throughout the century.

At $100 \mathrm{hPa}$, none of the curves reveal any obvious trend over this 100 -yr period, possibly in connection with the averaging of opposite tropospheric and stratospheric effects.

Above the main flight levels at $10 \mathrm{hPa}$, aviation $\mathrm{CO}_{2}$ emissions cause a large cooling $(-0.25 \mathrm{~K})$ near the end of the century. A slight cooling is simulated for the CIC and non$\mathrm{CO}_{2}$ effects as well, reaching around $-0.05 \mathrm{~K}$ towards the end of the century.

\subsection{The three-dimensional structure of the aviation im- pact on the temperature of the atmosphere}

The globally averaged impact of aviation does not provide a picture of the spatial distribution of its magnitude and of the statistical significance of the changes. In this section, we examine the changes in the near-surface temperature and the zonal means over the 20 -yr periods already used. In order to draw a picture of the seasonality of the impacts, we also calculate the monthly variations of the temperature changes. 

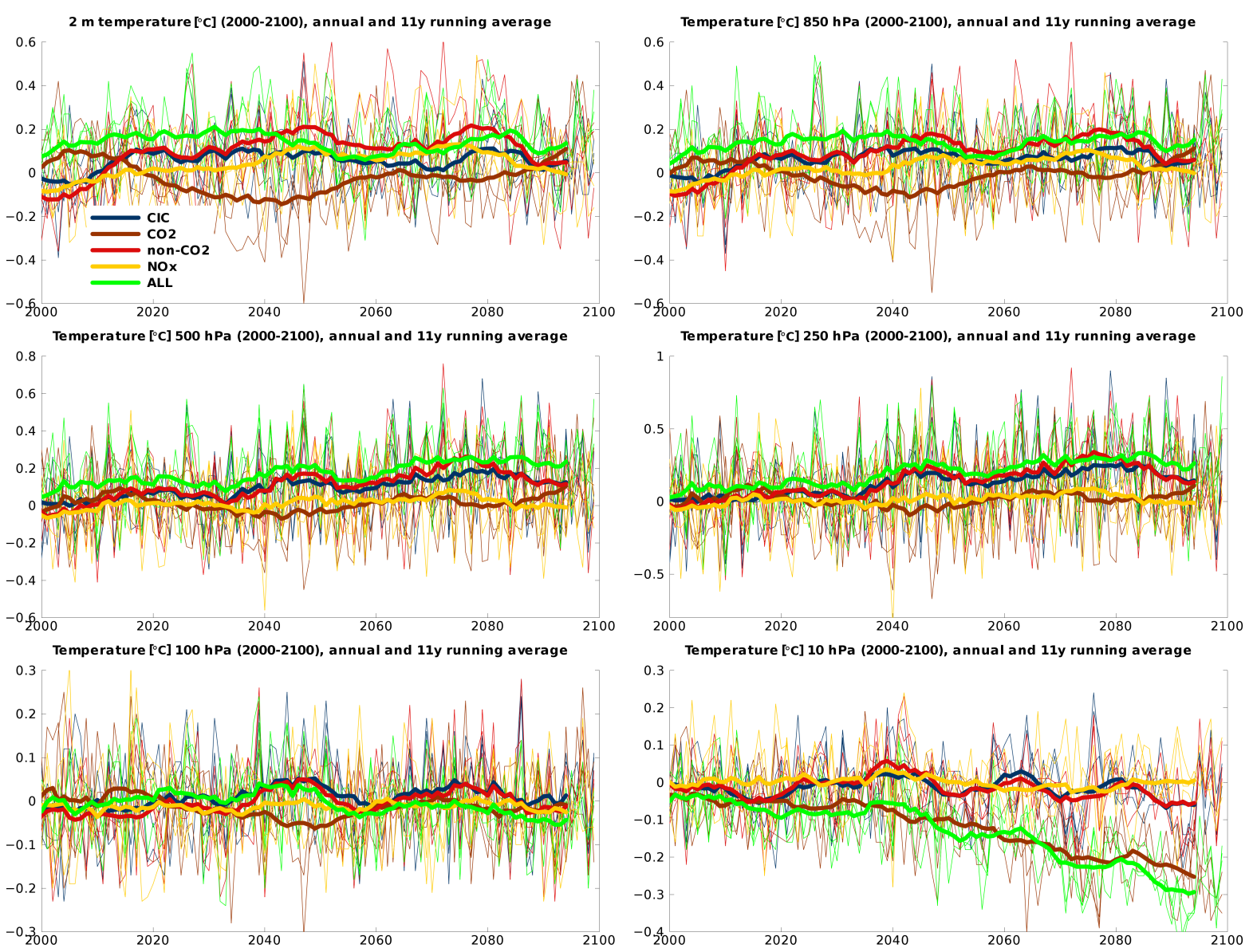

Fig. 9. Time series of the impact of aviation emissions on global temperature between 2000 and 2100 at six different pressure levels. Thin lines indicate the annual impact from each of the three members of a simulation, and the thick lines indicate the 11-yr running average of the ensemble mean. The blue, brown, red, yellow and green lines correspond to the $\mathrm{CIC}, \mathrm{CO}_{2}$, non- $\mathrm{CO}_{2}$ and $\mathrm{NO}_{\mathrm{x}}$ impacts, and the Total aviation impact, respectively.

\subsubsection{Spatial patterns of the near-surface temperature changes}

In Fig. 10, the change in the global near-surface temperature due to different aviation emissions is presented for the three periods, corresponding to the three columns from left to right.

The figure shows that the $\mathrm{CO}_{2}$ impact (first row) is mostly very small in the present-day and 2031-2050 periods, with, however, a warming above $0.1 \mathrm{~K}$ over the Antarctic and a cooling of up to $0.6 \mathrm{~K}$ over the Arctic, respectively. For the end of the 21st century, $\mathrm{CO}_{2}$ from aviation causes a warming of around $0.1 \mathrm{~K}$ over large parts of the globe; however, it is significant only over limited regions of the Pacific, the subtropical Atlantic and the Antarctic.

The impact of aviation $\mathrm{NO}_{\mathrm{x}}$ emissions (second row) on the near-surface temperature is small in general, and statistically significant over restricted areas with both warmings and coolings in the $-0.3-0.3 \mathrm{~K}$ range. The largest temperature changes (warmings) are modeled over the Arctic, especially in the near future. However, this should be viewed with caution, given the deficiencies identified in the sea-ice patterns and evolution we simulated (see Sect. 3.1).

The CIC impact on the near-surface temperature suggests warming, although it is statistically significant only over small regions in all periods. The warming can reach as much as $0.3-0.5 \mathrm{~K}$ in the near and far future.

The non- $\mathrm{CO}_{2}$ impact (Fig. 10, fourth row) resembles the CIC effect, reflecting the low $\mathrm{NO}_{\mathrm{x}}$ impact modeled in our study. It shows similar warming patterns over the Arctic as the $\mathrm{NO}_{\mathrm{x}}$ effect, probably reflecting similar sea-ice behavior in the region. The non- $\mathrm{CO}_{2}$ impact is, in general, stronger than the CIC one and represents a warming around $0.1-0.2 \mathrm{~K}$ in the far future, although the areas with significant changes are again limited.

More significant impacts are obtained when considering the combined effects of the emissions (Fig. 10, bottom row). The warming near the surface is significant during each examined time slice. It can be as high as $0.6 \mathrm{~K}$ over some 


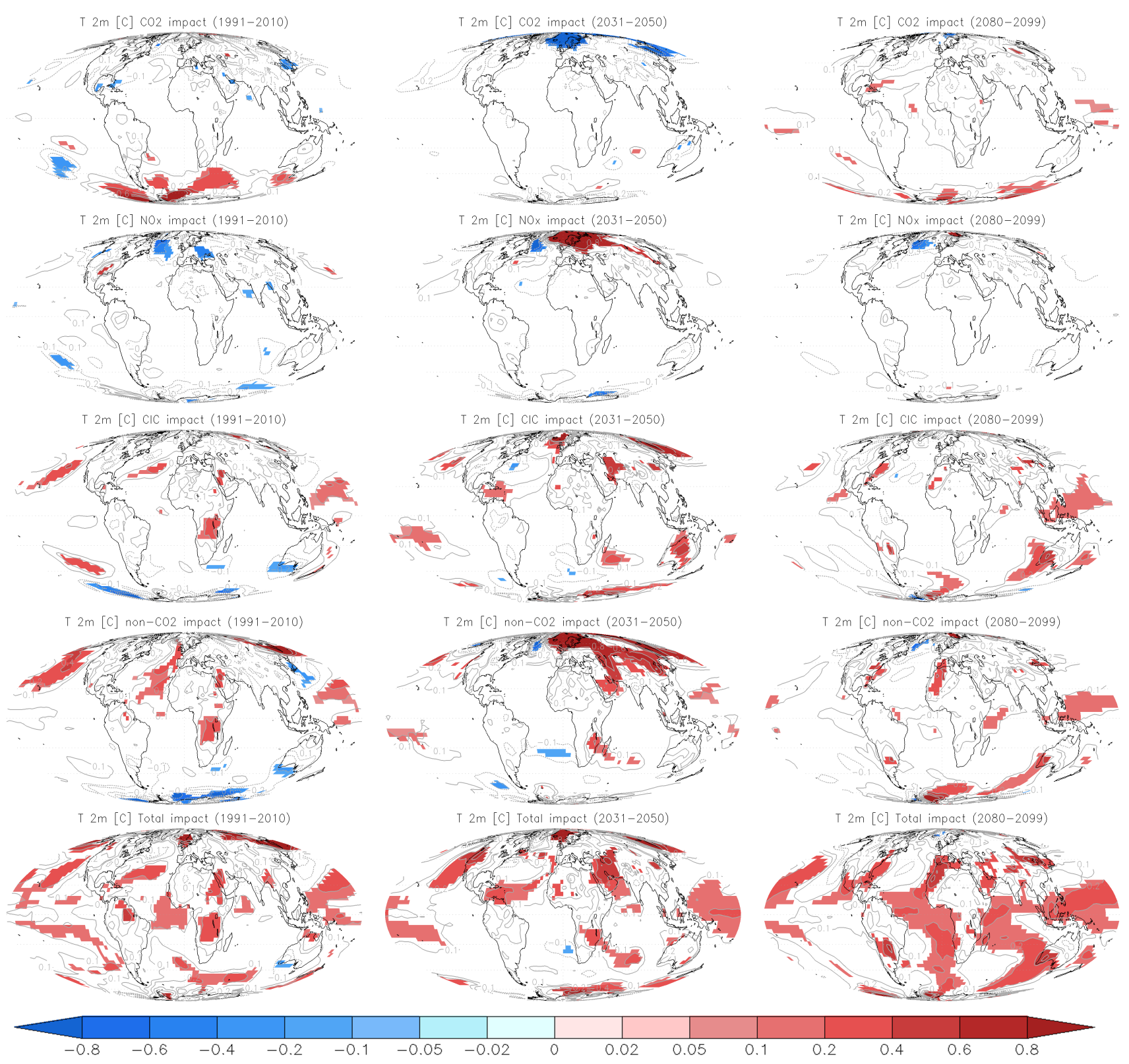

Fig. 10. Impact of aviation on near-surface temperature averaged over 1991-2010 (left column), 2031-2050 (middle column) and 2088-2099 (right column). Rows represent the $\mathrm{CO}_{2}$ (first row), $\mathrm{NO}_{\mathrm{x}}$ (second row), $\mathrm{CIC}$ (third row), non- $\mathrm{CO}_{2}$ (fourth row) and all the aviation effects (fifth row). The shaded areas correspond to statistically significant changes at the $95 \%$ level of confidence when applying a t-test.

regions in each period, but the area of statistical significance, largely over the oceans where the variability is lower, increases towards the end of the century, when the warming is usually above $0.1 \mathrm{~K}$.

\subsubsection{Zonal mean temperature changes due to aviation emissions}

This section provides the zonally averaged temperature response over the three periods analyzed in the previous sec- tion. The results are presented in Fig. 11, where each row again corresponds to a particular emission or their combinations (from top to bottom: $\mathrm{CO}_{2}, \mathrm{NO}_{\mathrm{x}}, \mathrm{CIC}$, non- $\mathrm{CO}_{2}$ and Total impact). The figure suggests that aviation emissions are, in general, responsible for warming in the troposphere and cooling in the stratosphere. The main causes of the stratospheric cooling are $\mathrm{CO}_{2}$ emissions (and the consequent increase in emissivity into space; see Sect. 4), and this is why this cooling is well expressed in the "Total" impact as well. The $\mathrm{CO}_{2}$ impact remains negligible in present-day 

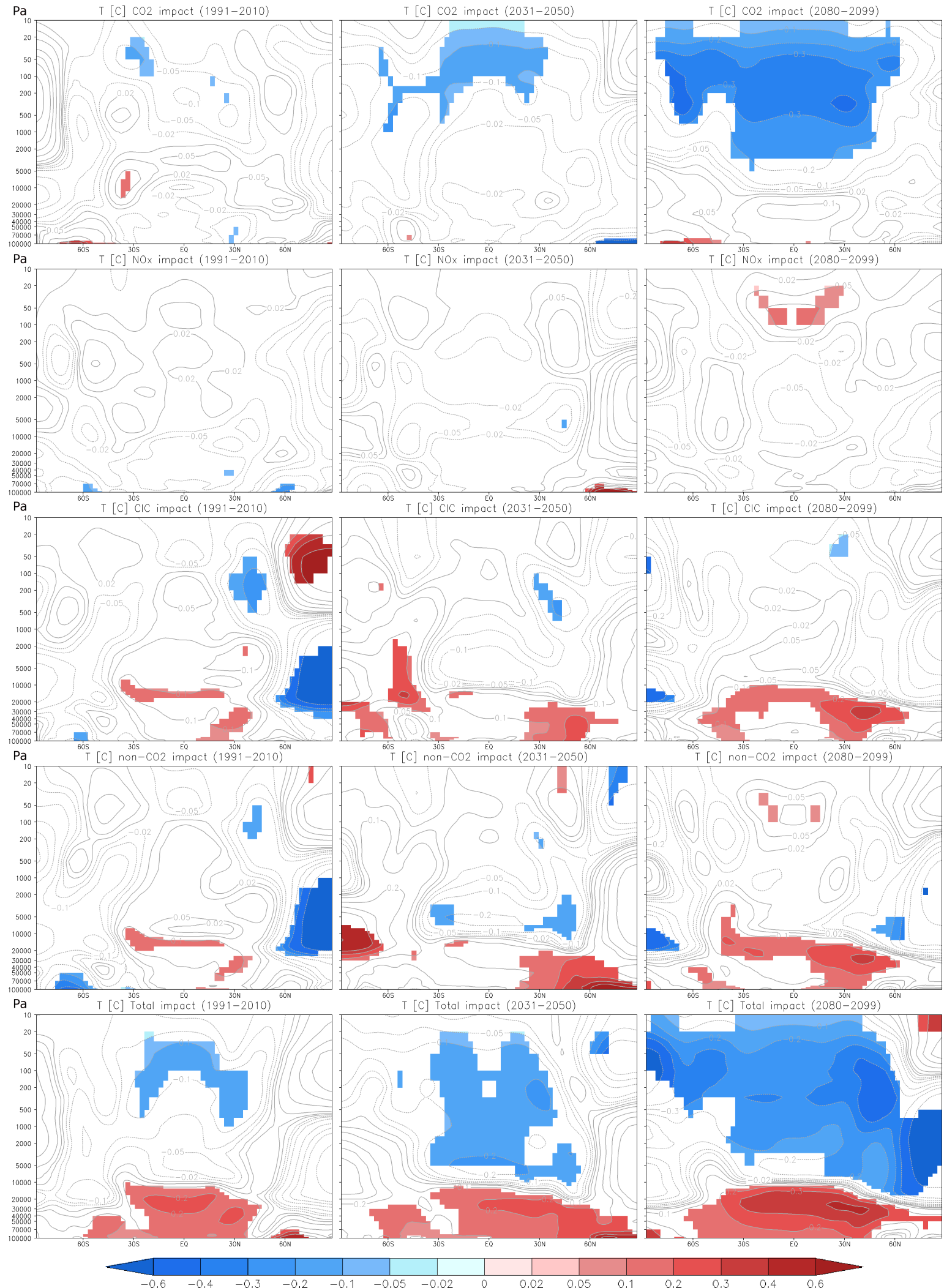

Fig. 11. Zonally averaged impact of aviation emissions on temperature over 1991-2010 (left column), 2031-2050 (middle column) and 20882099 (right column). The rows (from top to bottom) represent the impact of $\mathrm{CO}_{2}$, of $\mathrm{NO}_{\mathrm{x}}$ emissions, of $\mathrm{CIC}$, of the non- $\mathrm{CO}_{2}$ emissions and of the all the emissions considered (Total impact). The shaded areas represent statistically significant changes at the $95 \%$ level of confidence when applying a t-test. The vertical axis corresponds to pressure in $\mathrm{Pa}$. 
conditions, reaches -0.1 to $-0.2 \mathrm{~K}$ in the middle of the century, and becomes strongest towards the end of the century ( -0.3 to $-0.4 \mathrm{~K})$. In the troposphere, the $\mathrm{CO}_{2}$-caused warming exceeds $0.1 \mathrm{~K}$ in the far future over the tropical regions. It is not statistically significant, however.

The impact of $\mathrm{NO}_{\mathrm{x}}$ emissions does not appear to be statistically significant either, except over the Equator between 20 and $100 \mathrm{~Pa}$, probably in connection with increased ozone (see Fig. 8).

The CIC-related zonal mean temperature changes encompass warming in present-day conditions (up to $0.1-0.2 \mathrm{~K}$ ) over the equatorial latitudes, which have low statistical significance. In 2031-2050, this warming becomes larger (up to $0.2 \mathrm{~K}$ ), but is significant only over $30-60^{\circ} \mathrm{N}$. In the far future, the temperature increase is clearly emphasized between $60^{\circ} \mathrm{S}$ and $60^{\circ} \mathrm{N}$, encountering maxima (of $0.3-0.4 \mathrm{~K}$ ) over latitudes corresponding to the denser aviation routes (40$50^{\circ} \mathrm{N}$, higher troposphere, see Fig. 3).

The aviation non- $\mathrm{CO}_{2}$ emission-induced temperature changes are again very similar to those due to the CIC impact. In the troposphere, the highest warmings are modeled over the Northern Hemisphere, with maxima over the Arctic in the near future, and around the main flight corridors in the far future (up to $0.3-0.4 \mathrm{~K}$ ).

Finally, the overall aviation emissions induce a wellexpressed and statistically significant decrease in the stratospheric temperatures (up to $0.4-0.5 \mathrm{~K}$ ), and an intensive and statistically significant temperature increase in the troposphere in each of these three periods. In the near and far future, this increase covers almost all latitudes, and reaches maxima of $0.4-0.6 \mathrm{~K}$.

\subsubsection{Seasonal dependence of the aviation impacts on temperature}

Aviation emissions are not uniformly distributed along the year, but show a monthly variation with approximately $12 \%$ higher fuel burns in July-August than in winter, and this seasonal variation is represented in the emission data we use as well as in many other data sets (see Olsen et al., 2013). Furthermore, the environmental conditions under which these emissions trigger further effects, such as temperature, prevailing winds, humidity, etc., vary by season as well. Therefore, we might also expect a seasonal dependence of the impacts of the aviation emissions. To quantify this dependence, we plotted the change in the monthly variation of temperature (see Fig. 12), providing information about the seasonal variation of the impact at all altitudes.

The main features of the impacts seen in the previous paragraphs also appear in Fig. 12, i.e., (1) during 1991 to 2010: the low, statistically insignificant impacts of the $\mathrm{CO}_{2}$ and $\mathrm{NO}_{\mathrm{x}}$ emissions, and the stronger impacts for the CIC, the non- $\mathrm{CO}_{2}$ and the total emissions; (2) in the far future: the stratospheric cooling due to $\mathrm{CO}_{2}$ and total emissions, and the greatest tropospheric warming.
Figure 12 further illustrates that the $\mathrm{CO}_{2}$ tropospheric impact is highest from late spring until autumn, with a maximum around September (above $0.1 \mathrm{~K}$ ). However, the changes remain below statistical significance in each month, with the exception of a small warming near the surface in September in the far future. The $\mathrm{CO}_{2}$ induced cooling in the stratosphere is significant in both the near and far future in almost all seasons, lying below $-0.2 \mathrm{~K}$ above the $10 \mathrm{hPa}$ level, which is in line with the impact on the evolution of the global mean temperature (Fig. 9).

For the $\mathrm{NO}_{\mathrm{x}}$ impact, only a small area of significant warming above $100 \mathrm{~Pa}$ is simulated throughout most of the year.

The significant CIC impact is largest during early autumn in the present-day period and increases in the middle and far future, with a shift in the maximum values of warming to June and July exceeding $0.2 \mathrm{~K}$.

The seasonal dependence of the non- $\mathrm{CO}_{2}$ impact is similar to the CIC impact, with a maximum tropospheric warming in September, a second local maximum for the near future in June, and a stronger warming in 2080-2099, peaking in the summer months.

The impact of all the emissions (total impact) is significant in every season in both the troposphere and the stratosphere, and in practically every examined period. The largest tropospheric warming occurs during October 1991 to 2010 and during the summer in the two future periods, reaching $0.4 \mathrm{~K}$ in the far future. The stratospheric cooling as a result of increased $\mathrm{CO}_{2}$, as expected, is present as well, reaching the same values as for the $\mathrm{CO}_{2}$ impact.

\section{Discussion and conclusions}

The present work assesses the impact of global aviation on climate using an AOGCM with online chemistry.

We identified two main aspects in the behavior of our model performance that have affected the results we analyzed. Indeed, the model simulated (1) unrealistic sea-ice amounts over the Arctic, and (2) a lower impact of the aviation $\mathrm{NO}_{\mathrm{x}}$ emissions on chemistry, in terms of ozone production, than previous studies. The first aspect is a shortcoming of our simulations that greatly influenced the surface and lower tropospheric temperatures, completely masking some of the individual impacts of aviation emissions. Therefore, the results we obtain for the surface temperature, in particular those for the northern high latitudes, should be viewed with caution. At higher levels from the middle troposphere to the upper stratosphere, our results, although statistically significant only to some extent, are consistent with the aviation RF expectations.

Overall, the changes in the global surface temperature that we simulate between 1860 and 2100 in our various experiments correspond to those of the IPCC (2007) or of Olivié et al. (2012), noting that our absolute surface temperatures are lower due to our biased sea-ice extent. Secondly, the 

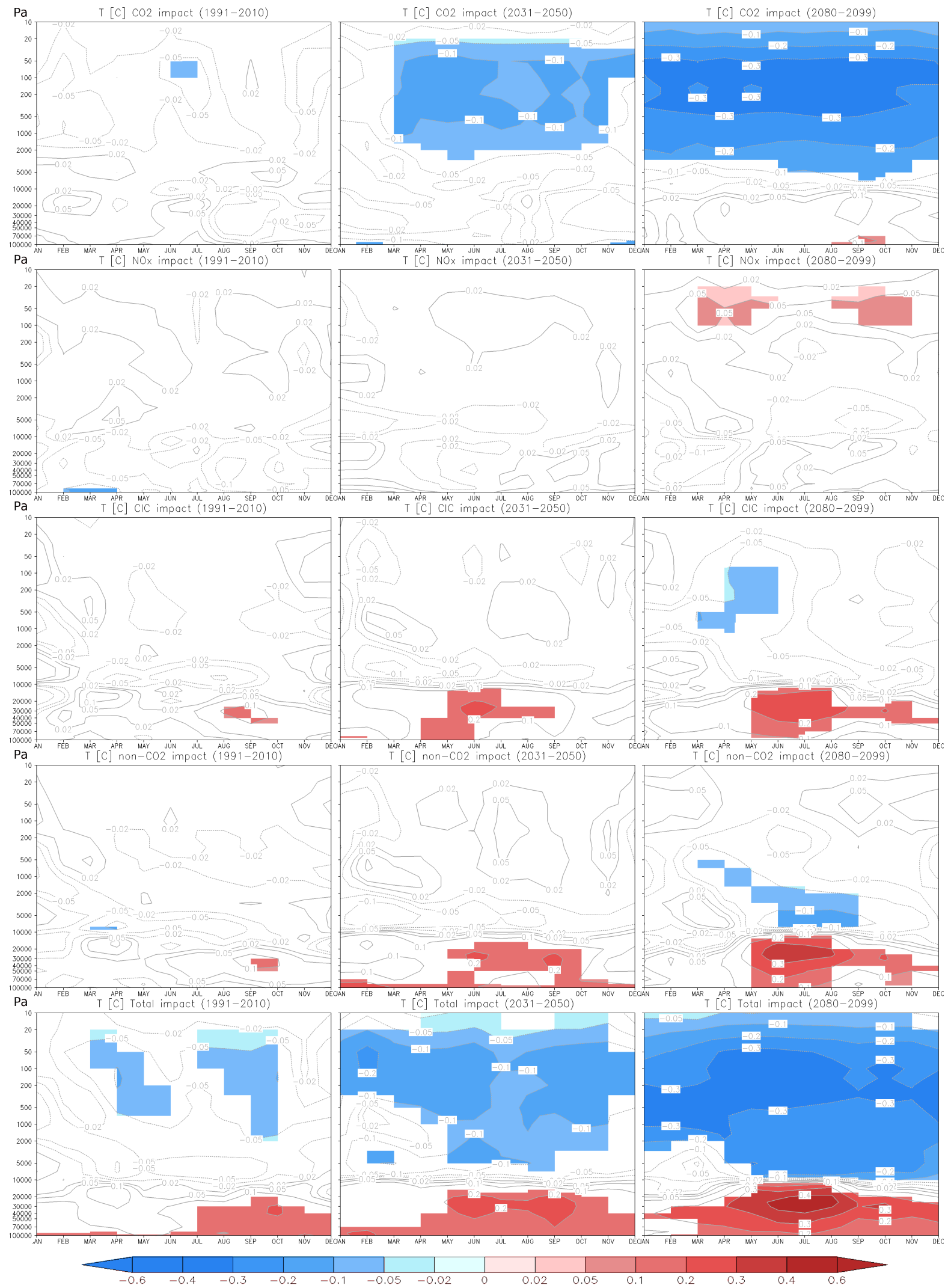

Fig. 12. Impact on the monthly global vertical profile of temperature due to aviation emissions averaged over 1991-2010 (left column), 2031-2050 (middle column) and 2080-2099 (right column). The rows represent the impact of $\mathrm{CO}_{2}$ and $\mathrm{NO}_{\mathrm{x}}$ emissions, of CIC, of the non- $\mathrm{CO}_{2}$ emissions and of all the emissions considered (Total impact). The shaded areas represent statistically significant changes at the $95 \%$ level of confidence when applying a t-test. The vertical axis corresponds to pressure in Pa. 

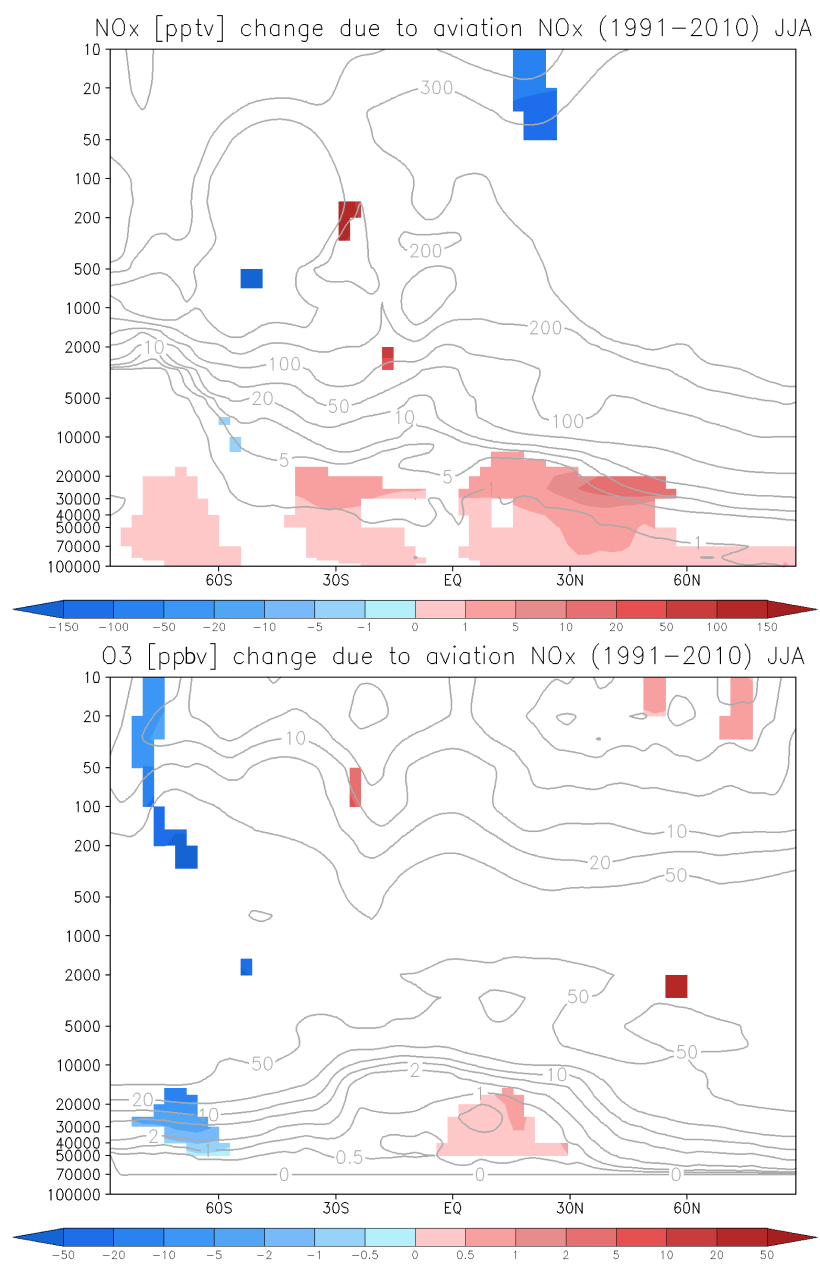

Fig. 13. The June-July-August impact of aircraft $\mathrm{NO}_{\mathrm{x}}$ emissions on the zonally averaged $\mathrm{NO}_{\mathrm{x}}$ (pptv) and $\mathrm{O}_{3}$ (ppbv) distributions for 1991-2010 and the standard deviation of the difference calculated from the members (contour lines). The shaded areas show significant changes at the $95 \%$ level of confidence. The vertical axis corresponds to pressure in $\mathrm{Pa}$.

averaged impact of aviation on temperatures is highly variable, probably due to the additional degree of freedom in our model with the introduction of online coupled chemistry, but the signal is more obvious at higher altitudes. As a consequence, the warming trends due to aviation are less clear than those in Olivié et al. (2012), and our impacts are usually of a smaller amplitude.

In general, the impact of the aviation $\mathrm{NO}_{\mathrm{x}}$ emissions on the temperature we simulate is negligible. This is in agreement with our computations of the quantity of ozone production resulting from these emissions, which is smaller than in previous studies (e.g., Grewe et al., 2002a; Isaksen, 2003; Gauss et al., 2006; Köhler et al., 2008; Cariolle et al., 2009; Hoor et al., 2009; Koffi et al., 2010; Hodnebrog et al., 2012). These studies report zonal ozone increases in the UTLS from 2 to 3 ppvb in Cariolle et al. (2009); Olivié et al. (2012) to over

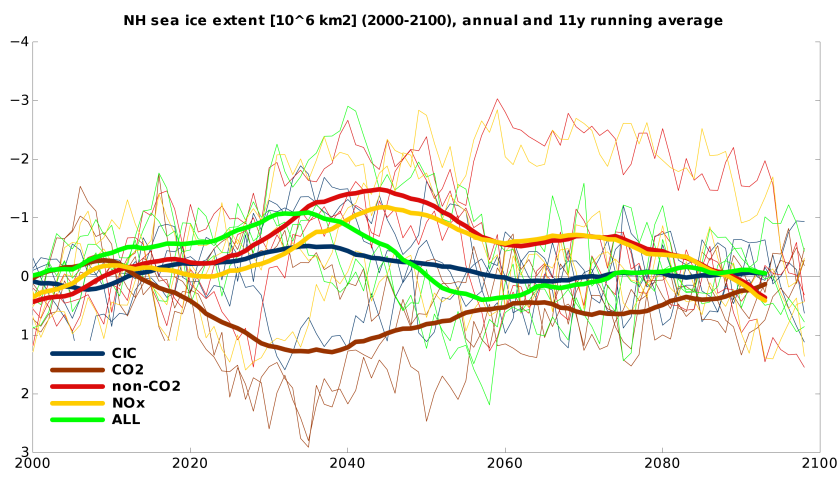

Fig. 14. Time series of the aviation emissions impacts on the northern hemispheric sea-ice area in September between 2000 and 2100. Thin lines indicate the annual impact of each of the three members of a simulation, and the thick lines indicate the 11-yr running average of the ensemble mean. The blue, brown, red, yellow and green lines correspond to the $\mathrm{CIC}, \mathrm{CO}_{2}$, non- $\mathrm{CO}_{2}$ and $\mathrm{NO}_{\mathrm{x}}$ impacts, and the Total aviation impact, respectively.

6 ppbv in Gauss et al. (2006); Köhler et al. (2008); Hoor et al. (2009), while our increase does not exceed 1 ppbv. There are several causes of this. First, we have not implemented the NMHC chemistry specific to the troposphere in our chemistry scheme, which has been shown to augment the ozone production (see Sect. 3.2). Secondly, we implemented the $\mathrm{NO}_{\mathrm{x}}$-plume parameterization of Cariolle et al. (2009) in our model, and this leads to a further decrease in ozone production. Thirdly, the aviation $\mathrm{NO}_{\mathrm{x}}$ induced changes were calculated as the difference of two experiments, each one with its own meteorology, in contrast with previous studies, where a fixed meteorology was imposed. In Fig. 13, we show the standard deviation for the aviation-imposed $\mathrm{NO}_{\mathrm{x}}$ and ozone changes for 1991-2010. The standard deviation of the $\mathrm{NO}_{\mathrm{x}}$ change is about $25-50 \%$ of the absolute change, and that of the ozone is close to $100 \%$. Hoor et al. (2009) calculated the intermodel standard deviation of the aviation $\mathrm{NO}_{\mathrm{x}}$ induced ozone changes, and found a much lower variability.

Then, considering that we imposed tropospheric methane relaxation values using the information from other global chemistry transport models that calculate the whole tropospheric chemistry (Hodnebrog et al., 2011), the weak positive $\mathrm{RF}$ due to the low ozone production is largely offset by the negative RF from the prescribed methane change evolution, leading to a non-significant $\mathrm{NO}_{\mathrm{x}}$ impact on temperature.

Our modeled ozone decreases in the stratosphere are consistent with previous studies. E.g., Köhler et al. (2008) report decreases of up to $-6 \mathrm{ppbv}$. However, it should be noted that these changes represent no more than a few percent of the original field, and that the standard deviation of these changes is comparable to the changes themselves (see Fig. 13). 
The impact of contrails and contrail-induced cloudiness (CIC) is clearly seen in our simulations, with a wellpronounced warming in the whole troposphere up to $0.3 \mathrm{~K}$ in zonal mean at the end of the 21 st century. The warming near the surface is, however, usually not statistically significant. The highest impacts are modeled for the Northern Hemisphere around the flight corridors, especially during summer, when clear sky conditions are frequent and aviation transport peaks.

Previously, Ponater et al. (2005) had calculated the contrail cirrus equilibrium climate response using scaled contrail coverage following the FESG/Fa1 inventory for 2050 aviation. The distribution of their zonal mean temperature response is very similar to our results, showing maximum warming around $300 \mathrm{hPa}$ between $30^{\circ}$ and $60^{\circ} \mathrm{N}$ and a statistically significant response (on the $95 \%$ level) usually below the tropopause, which is consistent with our results. More recently, Rap et al. (2010) made similar equilibrium calculations, but for the linear-shaped contrails, with 100 times enhanced optical depth-finding $0.13 \mathrm{~K}$ global average surface warming for present-day conditions against the reference simulation without contrails. We simulated almost no significant warming for the present-day period, due to the combined effect of linear-shaped contrails and contrailinduced cirrus.

However, these comparisons between our study and those of Ponater et al. (2005) and Rap et al. (2010) must be interpreted with caution because of the differences in modeling approaches.

The non- $\mathrm{CO}_{2}$ impact is very similar to the $\mathrm{CIC}$ impact in our simulations, as our non- $\mathrm{CO}_{2}$ effects include only the $\mathrm{NO}_{\mathrm{x}}$ and CIC effects, since we do not consider aviation aerosol emissions, and reflects the low $\mathrm{NO}_{\mathrm{x}}$ impact. Olivié et al. (2012) simulated a $0.25 \mathrm{~K}$ surface warming due to non$\mathrm{CO}_{2}$ emissions in 2100, which is higher than ours (less than $0.2 \mathrm{~K})$.

In terms of zonal mean changes, the warming during the far future (2080-2100) due to aviation non- $\mathrm{CO}_{2}$ emissions reaches $0.3 \mathrm{~K}$, which is again lower than the $0.45 \mathrm{~K}$ warming in Olivié et al. (2012), but the zonal distribution of the temperature response is rather similar, with the maximum change around the $300 \mathrm{hPa}$ level between $30^{\circ}$ and $60^{\circ} \mathrm{N}$ and even with a temperature decrease over the tropopause in both cases, although statistically not significant in our study.

For the $\mathrm{CO}_{2}$ effects, the modeled near-surface warming reaches $0.1 \mathrm{~K}$ over many regions in the far future, but is usually not significant. A cooling appears in the middle of the century over the Arctic. A similar cooling, although of lower magnitude, was computed by Olivié et al. (2012). In our case, it is connected to the Arctic sea ice in the simulations. Indeed, the variations in the Arctic sea-ice extent in September due to the various aviation emissions (see Fig. 14) are fully in line with those of the global temperature at the surface and at 850 $\mathrm{hPa}$ (see Fig. 9). These sea-ice variations do not appear to be scientifically consistent with changes in emissions, and thus with the corresponding radiative forcing, but rather seem to result from the sea-ice internal model variability. As an illustration of these affirmations, there is clearly much more Arctic sea ice in the $\mathrm{CO}_{2}$ impact case, with maximum peaking in 2030-2040 (see Fig. 14, brown curve), while for the lower tropospheric temperature, negative impacts are modeled, with a peak in 2040 (see Fig. 9, brown curve). Similarly, evident links appear for the $\mathrm{NO}_{\mathrm{x}}$ and non- $\mathrm{CO}_{2}$ impacts.

A small aviation $\mathrm{CO}_{2}$ warming is modeled over the Antarctic and the tropics at altitudes corresponding to the main flight levels, reaching $0.1 \mathrm{~K}$ in zonal mean in the far future. This warming is most pronounced in the late northern hemispheric summer, although these results do not reach statistical significance.

Sausen and Schumann (2000) made climate projections of the aviation emissions, focusing on the $\mathrm{CO}_{2}$ impact. Following their Fa1, Eab and Eah emission scenarios, they calculated warmings of $0.025,0.033$ and $0.050 \mathrm{~K}$ in 2050 and of $0.047,0.086$ and $0.146 \mathrm{~K}$ in 2100 , respectively. The scenario we used lies between their Eab and Eah scenarios, thus our warming at the end of the 21 st century $(0.1 \mathrm{~K}$ in the free troposphere) is consistent with theirs.

The total impact of aviation emissions simulated corresponds to a well-pronounced warming in the troposphere, which is statistically significant in both present and future decades. Near the surface, the warming reaches around $0.2 \mathrm{~K}$ by the end of the century, which is a lower value than that given by the corresponding scenario in Skeie et al. (2009) $(0.3 \mathrm{~K})$, who used a simple climate model.

The stratospheric cooling calculated for the "Total" impact (up to $-0.3 \mathrm{~K}$ ) resembles the cooling of the $\mathrm{CO}_{2}$ impact and lies in the increased thermal emissivity of $\mathrm{CO}_{2}$ in the stratosphere, resulting in enhanced radiation into space (Ramaswamy et al., 2001; Bell et al., 2010).

Our experiments show that the temperature response due to a radiative forcing may have, in general, a different geographical pattern than that of the radiative forcing itself, which has previously been shown by Joshi et al. (2003), Hansen et al. (2005) and Ponater et al. (2005). This is particularly the case with the $\mathrm{CO}_{2}$ impact, where the maximum aviation $\mathrm{CO}_{2}$ contribution is seen over the Northern Hemisphere, but the largest warming is modeled over the tropics and the Southern Hemisphere. Boer and Yu (2003) came to similar conclusions. In the case of the CIC effect, this behavior is less evident; according to the zonally averaged impacts, the largest temperature response follows the geographical location of the densest air traffic and thus the CIC occurrence.

The results shown here are clearly marked by low statistical significance. The modeling approach used, i.e., no scaling of aviation emissions, three member ensembles, and an AOGCM with online coupled chemistry, would require similar companion studies to confirm or infirm these results. Future improvement of our model will consider the implementation of a tropospheric chemistry scheme that should better resolve the chemical perturbation triggered by aviation 
emissions. Moreover, the issue of an improper sea-ice extent reference state, linked to large differences in the resolutions of the atmospheric and oceanic models, needs to be investigated further. An incorrect sea-ice reference state may strongly bias the near-surface temperature impact of aviation. Finally, a more accurate treatment of contrail and contrailinduced cloudiness as a function of their evolving microphysics would be beneficial to a study of the impact of aviation emissions.

Acknowledgements. This work was carried out as part of the "Impact du Transport Aérien sur l'Atmosphère et le Climat" (ITAAC) project, with support from the "Réseau Thématique de Recherche Avancée Science et Technologie pour l'Aéronautique et l'Espace" foundation. We further acknowledge the funding from the Ministry of Education of the Czech Republic (Research Plan No. MSM 0021620860) as well as the PRVOUK program - Environmental Research of the Charles University in Prague. The authors wish to thank Activity 1 of the QUANTIFY project for creating aviation emission estimates. Supercomputing time was provided by the Meteo-France/DSI supercomputing center. We gratefully acknowledge this support. We also thank Debra A. Bellon for the English correction provided. Finally, we would like to thank reviewers for their valuable comments and recommendations, which were of great assistance. Figures were created using the GrADS graphic package.

Edited by: P. Jöckel

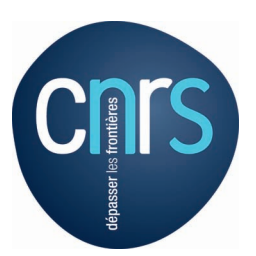

The publication of this article is financed by CNRS-INSU.

\section{References}

Atlas, D., Wang, Z., and Duda, D. P.: Contrails to cirrus morphology, microphysics, and radiative properties, J. Appl. Meteor. Climatol., 45, 5-19, 2006.

Balkanski, Y., Myhre, G., Gauss, M., Rädel, G., Highwood, E. J., and Shine, K. P.: Direct radiative effect of aerosols emitted by transport: from road, shipping and aviation, Atmos. Chem. Phys., 10, 4477-4489, doi:10.5194/acp-10-4477-2010, 2010.

Berntsen, T. K. and Isaksen, I. S. A.: Effects of lightning and convection on changes in upper tropospheric ozone due to aircraft, Tellus B, 51, 766-788, 1999.

Bell, C. J., Gray, L. J., and Kettleborough, J.: Changes in Northern Hemisphere stratospheric variability under increased $\mathrm{CO} 2$ concentrations, Q. J. Roy. Meteor. Soc., 136, 1181-1190, 2010.

Boer, G. J. and Yu, B.: Climate sensitivity and response, Clim. Dynam., 20, 415-429, doi:10.1007/s00382-002-0283-3, 2003.

Boucher, O.: Air traffic may increase cirrus cloudiness, Nature, 397 , 30-31, 1999.
Burkhardt, U. and Kärcher, B.: Global radiative forcing from contrail cirrus, Nature Clim. Change, 1, 54-58, doi:10.1038/NCLIMATE1086, 2011.

Cariolle, D. and Teyssèdre, H.: A revised linear ozone photochemistry parameterization for use in transport and general circulation models: multi-annual simulations, Atmos. Chem. Phys., 7, 2183 2196, doi:10.5194/acp-7-2183-2007, 2007.

Cariolle, D., Caro, D. Paoli, R., Hauglustaine, D. A., Cuénot, B., Cozic, A., and Paugam, R.: Parameterization of plume chemistry into large-scale atmospheric models: application to aircraft $\mathrm{NO}_{\mathrm{x}}$ emissions, J. Geophys. Res., 114, D19302, doi:10.1029/2009JD011873, 2009.

Chen, C.-C. and Gettelman, A.: Simulated radiative forcing from contrails and contrail cirrus, Atmos. Chem. Phys. Discuss., 13, 10939-10959, doi:10.5194/acpd-13-10939-2013, 2013.

Eisenman, I., and Wettlaufer, J. S.: Nonlinear threshold behavior during the loss of Arctic sea ice, Proc. Nat. Acad. Sci. USA, 106, 28-32, doi:10.1073/pnas.0806887106, 2009.

FESG: ICAO/CAEP Forecasting and Economic Sub-Group (FESG) CAEP/8 Traffic and fleet forecasts Paper presented to CAEP Steering Group 19/08/08, ref. CAEP-SG/20082-IP/02, 2008.

Fetterer, F., Knowles, K., Meier, W., and Savoie, M.: Sea Ice Index, Boulder, Colorado USA: National Snow and Ice Data Center, http://dx.doi.org/10.7265/N5QJ7F7W, 2009.

Frömming, C., Ponater, M., Burkhardt, U., Stenke, A., Pechtl, S., and Sausen, R.: Sensitivity of contrail coverage and contrail radiative forcing to selected key parameters, Atmos. Environ., 45, 1483-1490, 2011.

Gao, R. S., Fahey, D. W., Popp, P. J., Marcy, T. P., Herman, R. L., Weinstock, E. M., Smith, J. B., Sayres, D. S., Pittman, J. V., Rosenlof, K. H., Thompson, T. L., Bui, P. T., Baumgardner, D. G., Anderson, B. E., Kok, G., and Weinheiner, A. J.: Measurements of relative humidity in a persistent contrail, Atmos. Env., 40, 1590-1600, 2006.

Gauss, M., Isaksen, I. S. A., Lee, D. S., and Sovde, O. A.: Impact of aircraft $\mathrm{NO}_{\mathrm{x}}$ emissions on the atmosphere tradeoffs to reduce the impact, Atmos. Chem. Phys., 6, 1529-1548, doi:10.5194/acp-61529-2006, 2006.

GISS (Goddard Institute for Space Studies), Surface Temperature Analysis, http://data.giss.nasa.gov/gistemp/, 2010.

Grewe, V.: Lightning $\mathrm{NO}_{\mathrm{x}}$ emissions and the impact on the effect of aircraft emissions - Results from the EU-Project TRADEOFF. Proceedings of the AAC-Conference, 30 June to 3 July, Friedrichshafen, Germany, 2003.

Grewe, V., Dameris, M., Fichter, C., and Sausen, R.: Impact of aircraft $\mathrm{NO}_{\mathrm{x}}$ emissions. Part 1: interactively coupled climatechemistry simulations and sensitivities to climate-chemistry feedback, lightning and model resolution, Meteorol. Z., 11, 177186, 2002a.

Grewe, V., Dameris, M., Fichter, C., and Lee, D. S.: Impact of aircraft $\mathrm{NO}_{\mathrm{x}}$ emissions. Part 2: effects of lowering the flight altitude, Meteorol. Z., 11, 197-205, 2002b.

Grewe, V., Shindell, D. T., and Eyring, V.: The impact of horizontal transport on the chemical composition in the tropopause region: lightning $\mathrm{NO}_{\mathrm{x}}$ and streamers, Adv. Space Res., 33, 1058-1061, 2004.

Hansen, J., et al.: Efficacy of climate forcings, J. Geophys. Res., 110, D18104, doi:10.1029/2005JD005776, 2005. 
Hendricks, J., Kärcher, B., Döpelheuer, A., Feichter, J., Lohmann, U., and Baumgardner, D.: Simulating the global atmospheric black carbon cycle: a revisit to the contribution of aircraft emissions, Atmos. Chem. Phys., 4, 2521-2541, doi:10.5194/acp-4-2521-2004, 2004.

Hendricks, J., Kärcher, B., and Lohmann, U.: Effects of ice nuclei on cirrus clouds in a global climate model, J. Geophys. Res., 116, D18206, doi:10.1029/2010JD015302, 2009.

Hodnebrog, Ø., Berntsen, T. K., Dessens, O., Gauss, M., Grewe, V., Isaksen, I. S. A., Koffi, B., Myhre, G., Olivié, D., Prather, M. J., Pyle, J. A., Stordal, F., Szopa, S., Tang, Q., van Velthoven, P., Williams, J. E., and Ødemark, K.: Future impact of non-land based traffic emissions on atmospheric ozone and $\mathrm{OH}$ - an optimistic scenario and a possible mitigation strategy, Atmos. Chem. Phys., 11, 11293-11317, doi:10.5194/acp-11-11293-2011, 2011.

Hodnebrog, Ø., Berntsen, T. K., Dessens, O., Gauss, M., Grewe, V., Isaksen, I. S. A., Koffi, B., Myhre, G., Olivie, D., Prather, M. J., Stordal, F., Szopa, S., Tang, Q., van Velthoven, P., and Williams, J. E.: Future impact of traffic emissions on atmospheric ozone and $\mathrm{OH}$ based on two scenarios, Atmos. Chem. Phys., 12, 12211-12225, doi:10.5194/acp-12-12211-2012, 2012.

Hong, G., Yang, P., Minnis, P., Hu, Y. X., and North, G.: Do contrails significantly reduce daily temperature range?, Geophys. Res. Lett., 35, L23815, doi:10.1029/2008GL036108, 2008.

Hoor, P., Borken-Kleefeld, J., Caro, D., Dessens, O., Endresen, O., Gauss, M., Grewe, V., Hauglustaine, D., Isaksen, I. S. A., Jöckel, P., Lelieveld, J., Myhre, G., Meijer, E., Olivie, D., Prather, M., Schnadt Poberaj, C., Shine, K. P., Staehelin, J., Tang, Q., van Aardenne, J., van Velthoven, P., and Sausen, R.: The impact of traffic emissions on atmospheric ozone and $\mathrm{OH}$ : results from QUANTIFY, Atmos. Chem. Phys., 9, 3113-3136, doi:10.5194/acp-9-3113-2009, 2009.

Huszar, P., Cariolle, D., Paoli, R., Halenka, T., Belda, M., Schlager, H., Miksovsky, J., and Pisoft, P.: Modeling the regional impact of ship emissions on $\mathrm{NO}_{\mathrm{x}}$ and ozone levels over the Eastern Atlantic and Western Europe using ship plume parameterization, Atmos. Chem. Phys., 10, 6645-6660, doi:10.5194/acp-106645-2010, 2010.

IPCC: Aviation and the global atmosphere, in: Intergovernmental Panel on Climate Change, edited by: Penner, E., Lister, J., Griggs, D. H., Griggs, D. J., Dokken, D. J., and McFarland, M., Cambridge University Press, Cambridge, UK, 1999.

IPCC: Climate change 2007: the physical science basis. Contribution of working group I to the fourth assessment report of the intergovernmental panel on climate change, Cambridge 15 University Press, Cambridge, UK and New York, NY, USA, 2007.

Isaksen, I. S. A (Ed.): Aircraft emissions: Contributions of various climate compounds to changes in composition and radiative forcing - Tradeoff to reduce atmospheric impact (TRADEOFF). Final report to the Commission of European Communities, European Commission DG XII, Brussels, Contract No EVK2-CT1999-0030, 2003.

Johnston, H.: Reduction of stratospheric ozone by nitrogen oxide catalysts from supersonic transport exhaust, Science, 173, 3996, doi:10.1126/science.173.3996.517, 1971.

Johnston, H. S. and Quitevis, E.: The Oxides of Nitrogen with Respect to Urban Smog, Supersonic Transports, and Global Methane. International Congress of Radiation Research, US De- partment of Transportation and US Atomic Energy Committee, Seattle, Washington, 14-20 July 1974.

Jones, P. W.: Conservative remapping: first-and second-order conservative remapping, Mon. Weather. Rev., 127, 2204-2210, 1999.

Joshi, M., Shine, K., Ponater, M., Stuber, N., Sausen, R., and Li, L.: A comparison of climate response to different radiative forcings in three general circulation models: towards an improved metric of climate change, Clim. Dynam., 20, 843-854, 2003.

Kentarchos, A. S., and Roelofs, G. J.: Impact of aircraft $\mathrm{NO}_{\mathrm{x}}$ emissions on tropospheric ozone calculated with a chemistry-general circulation model: Sensitivity to higher hydrocarbon chemistry, J. Geophys. Res., 107, doi:10.1029/2001JD000828, 2002.

Koffi, B., Szopa, S., Cozic, A., Hauglustaine, D., and van Velthoven, P.: Present and future impact of aircraft, road traffic and shipping emissions on global tropospheric ozone, Atmos. Chem. Phys., 10, 11681-11705, doi:10.5194/acp-10-11681-2010, 2010.

Köhler, M. O., Rädel, G., Dessens, O., Shine, K. P., Rogers, H. L., Wild, O., and Pyle, J. A.: Impact of perturbations to nitrogen oxide emissions from global aviation, J. Geophys. Res., 113, D11305, doi:10.1029/2007JD009140, 2008.

Kraabøl, A. G., Berntsen, T. K., Sundet, J. K., and Stordal, F.: Impacts of $\mathrm{NO}_{\mathrm{x}}$ emissions from subsonic aircraft in a global three-dimensional chemistry transport model including plume processes, J. Geophys. Res., 107, 4655, doi:10.1029/2001JD001019, 2002.

Lee, D. S., Owen, B., Graham, A., Fichter, C., Lim, L. L., and Dimitriu, D.: Allocation of International Aviation Emissions from Scheduled Air Traffic - Present Day and Historical (Report 2 of 3), Manchester Metropolitan University, Centre for Air Transport and the Environment, Manchester, UK, 2005.

Lee, D. S., Fahey, D. W., Forster, P. M., Newtone, P. J., Wit, R. C. N., Lim, L. L., Owen, B., and Sausen, R.: Aviation and global climate change in the 21st century, Atmos. Environ. 43, 3520-3537, 2009.

Lee, D. S., Pitari, G., Grewe, V., Gierens, K., Penner, J. E., Petzold, A., Prather, M. J., Schumann, U., Bai, A., Berntsen, T., Iachetti, D., Lim, L. L., and Sausen, R.: Transport impacts on atmosphere and climate: aviation, Atmos. Environ., 44, 46784734, 2010.

Lefèvre, F., Brasseur, G. P., Folkins, I., Smith, A. K., and Simon, P.: Chemistry of the 1991-1992 stratospheric winter: threedimensional model simulations, J. Geophys. Res., 99, 81838195, 1994.

Lim, L., Lee, D. S., Sausen, R., and Ponater, M.: Quantifying the effects of aviation on radiative forcing and temperature with a climate response model, in: Proceedings of an international conference on transport, atmosphere and climate (TAC), edited by: Sausen, R., Blum, A., Lee, D. S., and Brüning, C., 202-207, http://www.pa.op.dlr.de/tac/proceedings.html, 2007.

Liu, X., Penner, J.E., and Wang, M.: Influence of anthropogenic sulphate and black carbon on upper tropospheric clouds in the NCAR CAM3 model coupled to the IMPACT global aerosol model, J. Geophys. Res., 114, D03204, doi:10.1029/2008JD010492, 2009.

Madec, G.: NEMO ocean engine. Note du Pole de modelisation, Institut Pierre-Simon Laplace (IPSL), France, No 27 ISSN No 1288-1619, 2008. 
Michou, M., Saint-Martin, D., Teyssèdre, H., Alias, A., Karcher, F., Olivié, D., Voldoire, A., Josse, B., Peuch, V.-H., Clark, H., Lee, J. N., and Chéroux, F.: A new version of the CNRM Chemistry-Climate Model, CNRM-CCM: description and improvements from the CCMVal-2 simulations, Geosci. Model Dev., 4, 873-900, doi:10.5194/gmd-4-873-2011, 2011.

Mlawer, E. J., Taubman, S. J., Brown, P. D., Iacono, M. J., and Clough, S. A.: Radiative transfer for inhomogeneous atmospheres: RRTM, a validated correlated-k model for the longwave, J. Geophys. Res., 102, 16663-16682, 1997.

Morcrette, J.-J., Mlawer, E. J., Iacono, M. J., and Clough, S. A.: Impact of the radiation-transfer scheme RRTM in the ECMWF forecasting system, ECMWF Newsletter No. 91, Summer 2001.

Morgenstern O., Giorgetta, M. A., Shibata, K., Eyring, V., Waugh, D. W., G. Shepherd, T., Akiyoshi, H., Austin, J., Baumgaertner, A. J. G., Bekki, S., Braesicke, P., Brühl, C., Chipperfield, M. P., Cugnet, D., Dameris, M., Dhomse, S., Frith, S. M., Garny, H., Gettelman, A., Hardiman, S. C., Hegglin, M. I., Jöckel, P., Kinnison, D. E., Lamarque, J.-F., Mancini, E., Manzini, E., Marchand, M., Michou, M., Nakamura, T., Nielsen, J. E., Olivié, D., Pitari, G., Plummer, D. A., Rozanov, E., Scinocca, J. F., Smale, D., Strahan, S., Teyssèdre, H., Toohey, M., Tian, W., and Yamashita, Y.: Review of present-generation stratospheric chemistry-climate models and associated external forcings, J. Geophys. Res., 115, D00M02, doi:10.1029/2009JD013728, 2010.

Myhre, G., Shine, K. P., Rädel, G., Gauss, M., Isaksen, I. S. A., Tang, Q., Prather, M. J., Williams, J. E., van Velthoven, P., Dessens, O., Koffi, B., Szopa, S., Hoor, P., Grewe, V., Borken-Kleefeld, J., Berntsen, T. K., and Fuglestvedt, J. S.: Radiative forcing due to changes in ozone and methane caused by the transport sector, Atmos. Environ., 45, 387-394, doi:10.1016/j.atmosenv.2010.10.001, 2011.

Olivié, D. and Stuber, N.: Emulating AOGCM results using simple climate models, Clim. Dynam., 35, 1257-1287, doi:10.1007/s00382-009-0725-2, 2010.

Olivié, D. J. L., Cariolle, D., Teyssèdre, H., Salas, D., Voldoire, A., Clark, H., Saint-Martin, D., Michou, M., Karcher, F., Balkanski, Y., Gauss, M., Dessens, O., Koffi, B., and Sausen, R.: Modeling the climate impact of road transport, maritime shipping and aviation over the period 1860-2100 with an AOGCM, Atmos. Chem. Phys., 12, 1449-1480, doi:10.5194/acp-12-14492012, 2012.

Olsen, S. C., Wuebbles, D. J., and Owen, B.: Comparison of global 3-D aviation emissions datasets, Atmos. Chem. Phys., 13, 429441, doi:10.5194/acp-13-429-2013, 2013.

Osmundsen, J. A.: Weather Scientists are Optimistic that New Findings are Near, New York Times, 23 September, p. 1, 1963.

Owen, B., Lee, D. S., and Lim, L.: Flying into the future: aviation emissions scenarios to 2050, Environ. Sci. Technol., 44, 22552260, doi:10.1126/science.1196285, 2010.

Ponater, M., Marquart, S., Sausen, R., and Schumann, U.: On contrail climate sensitivity, Geophys. Res. Lett., 32, L10706, doi:10.1029/2005GL022580, 2005.

Ponater, M., Pechtl, S., Sausen, R., Schumann, U., and Hüttig, G.: A state-of-the-art assessment of the potential of the cryoplane technology to reduce aircraft climate impact, Atmos. Environ., 40, 6928-6944, 2006.

Ramaswamy, V., Chanin, M.-L., Angell, J., Barnett, J., Gaffen, D. J., Gelman, M., Keckhut, P., Koshelkov, Y., Labitzke, K., Lin, J.-J.
R., O’Neill, A., Nash, J., Randel, W., Rood, R., Shine, K., Shiotani, M., and Swinbank, R.: Stratospheric temperature trends: Observations and model simulations, Rev. Geophys. 39, 71-122, 2001.

Rap, A., Forster, P. M., Haywood, J. M., Jones, A., and Boucher, O.: Estimating the climate impact of linear contrails using the UK Met Office climate model, Geophys. Res. Lett., 37, L20703, doi:10.1029/2010GL045161., 2010.

Rosenlund, M., Berglind, N., Pershagen, G., Järup, L., and Bluhm, G.: Increased prevalence of hypertension in a population exposed to aircraft noise, Occup. Environ. Med., 58, 769-773, doi:10.1136/oem.58.12.769, 2001.

Salas Y Melia, D.: A global coupled sea-ice-ocean model, Ocean Model, 4, 137-172, 2002.

Sander, S. P., Friedl, R. R., Golden, D. M., Kurylo, M. J., Moortgat, G. K., Keller-Rudek, H., Wine, P. H., Ravishankara, A. R., Kolb, C. E., Molina, M. J., Finlayson-Pitts, B. J., Huie, R. E., and Orkin, V. L.: Chemical kinetics and photochemical data for use in atmospheric studies, Evaluation Number 15, JPL Publication 06-2, Jet Propulsion Laboratory, Pasadena, 2006.

Sausen, R. and Schumann, U.: Estimates of the climate response to aircraft $\mathrm{CO}_{2}$ and $\mathrm{NO}_{\mathrm{x}}$ emissions scenarios, Clim. Change, 44, 27-58, 2000.

Sausen, R., Isaksen, I., Grewe, V., Hauglustaine, D., Lee, D. S., Myhre, G., Köhler, M. O., Pitari, G., Schumann, U., Stordal, F., and Zerefos, C.: Aviation radiative forcing in 2000: an update of IPCC (1999), Meteorol. Z., 14, 555-561, 2005.

Schumann, U.: On conditions for contrail formation from aircraft exhausts, Meteorol. Z., 5, 4-23, 1996.

Schumann, U.: Formation, properties and climatic effects of contrails, C. R. Physique 6, 549-565, 2005.

Schumann, U. and Huntrieser, H.: The global lightning-induced nitrogen oxides source, Atmos. Chem. Phys., 7, 3823-3907, doi:10.5194/acp-7-3823-2007, 2007.

Skeie, R. B., Fuglestvedt, J., Berntsen, T., Lund, M. T., Myhre, G., and Rypdal, K.: Global temperature change from the transport sectors: Historical development and future scenarios, Atmos. Environ., 43, 6260-6270, 2009.

Stevenson, D. S., Doherty, R. M., Sanderson, M. G., Collins, W. J., Johnson, C. E., and Derwent, R. G.: Radiative forcing from aircraft $\mathrm{NO}_{\mathrm{x}}$ emissions: mechanisms and seasonal dependence, J. Geophys. Res. 109, D17307, doi:10.1029/2004JD004759, 2004.

Stordal, F., Myhre, G., Stordal, E. J. G., Rossow, W. B., Lee, D. S., Arlander, D. W., and Svendby, T.: Is there a trend in cirrus cloud cover due to aircraft traffic?, Atmos. Chem. Phys., 5, 2155-2162, doi:10.5194/acp-5-2155-2005, 2005.

Szopa, S., Balkanski, Y., Schulz, M., Bekki, S., Cugnet, D., Fortems-Cheiney, A., Turquety, S., Cozic, A. Déandreis, C., Hauglustaine, D., Idelkadi, A., Lathière, J., Lefevre, F., Marchand, M., Vuolo, R., Yan, N., and Dufresne, J.-L.: Aerosol and Ozone changes as forcing for Climate Evolution between 1850 and 2100, Clim. Dyn., 40, 2223-2250, doi:10.1 007/s00382-0121408-y, 2013.

SPARC: SPARC CCMVal Report on the Evaluation of ChemistryClimate Models: edited by: Eyring, V., Shepherd, T. G., and Waugh, D. W., SPARC Report No. 5, WCRP-132, WMO/TDNo. 1526, available at: http://www.atmosp.physics.utoronto.ca/ SPARC, 2010. 
Teyssèdre, H., Michou, M, Clark, H. L., Josse, B., Karcher, F., Olivié, D., Peuch, V.-H., Saint-Martin, D., Cariolle, D., Attié, J.-L., Nédélec, P., Ricaud, P., Thouret, V., van der A, R. J., VolzThomas, A., and Chéroux, F.: A new tropospheric and stratospheric Chemistry and Transport Model MOCAGE-Climat for multi-year studies: evaluation of the present-day climatology and sensitivity to surface processes, Atmos. Chem. Phys., 7, 58155860, 2007, http://www.atmos-chem-phys.net/7/5815/2007/.

Valcke, S.: OASIS3 user guide (prism_2-5). Technical report TR/CMGC/06/73, CERFACS, Toulouse, France, 60, 2006.

Voldoire, A., Sanchez-Gomez, E., Salas y Mélia, D., Decharme, B., Cassou, C., Sénési, S., Valcke, S., Beau, I., Alias, A., Chevallier, M., Déqué, M., Deshayes, J., Douville, H., Fernandez, E., Madec, G., Maisonnave, E., Moine, M.-P., Planton, S., SaintMartin, D., Szopa, S., Tyteca, S., Alkama, R., Belamari, S., Braun, A., Coquart, L., and Chauvin, F.: The CNRM-CM5.1 global climate model: description and basic evaluation, Clim. Dynam., 40, 2091-2121, doi:10.1007/s00382-011-1259-y, 2013.
Wilcox, L. J., Shine, K. P., and Hoskins, B. J.: Radiative forcing due to aviation water vapour emissions, Atm. Env., 63, 1-13, doi:j.atmosenv.2012.08.072, 2012.

Wilkerson, J. T., Jacobson, M. Z., Malwitz, A., Balasubramanian, S., Wayson, R., Fleming, G., Naiman, A. D., and Lele, S. K.: Analysis of emission data from global commercial aviation: 2004 and 2006, Atmos. Chem. Phys., 10, 6391-6408, doi:10.5194/acp-10-6391-2010, 2010.

Zerefos, C. S., Eleftheratos, K., Balis, D. S., Zanis, P., Tselioudis, G., and Meleti, C.: Evidence of impact of aviation on cirrus cloud formation, Atmos. Chem. Phys., 3, 1633-1644, doi:10.5194/acp-3-1633-2003, 2003. 